\title{
Long-Term Effect of Industrial Waste Water Irrigation on Soil Chemical Properties
}

\author{
Rafiqul Islam¹, Golam Kibria Muhammad Mustafizur Rahman ${ }^{2}$, Abu Raihan Muhammad Solaiman ${ }^{2}$ and Abu Saleque ${ }^{3}$ \\ 1. Chief Scientific Officer (Current Charge) \& Head, Bangladesh Rice Research Institute (BRRI), Rajshahi 6212, Bangladesh \\ 2. Department of Soil Science, Bangabandhu Sheikh Mujibur Rahman Agricultural University, Gazipur 1706, Bangladesh \\ 3. Coordinator for Advanced Studies and Research, Bangladesh Rice Research Institute BRRI, Gazipur 1701, Bangladesh
}

\begin{abstract}
A laboratory experiment was conducted in Soil Science Division of BRRI during 2011 aimed to determine the vertical distribution of soil chemical properties under long-term industrial waste water irrigated rice field. Waste water irrigated rice field seemed to create some differences in soil $\mathrm{pH}$ profile. $\mathrm{The}_{\mathrm{pH}}$ and $\mathrm{pH}_{\mathrm{KCl}}$ in all soil depth was higher with waste water irrigated rice field. The surface charge of both the soils was considerably negative. Waste water irrigated rice field developed more negative charges in soils. Irrigation with waste water increased Electrical Conductivity (EC) in rice soils profile. The organic carbon content (\%) started to decrease sharply with the increase in soil depth. Organic carbon content was higher with waste water irrigated rice soils. Total nitrogen (\%) was high with underground water irrigated rice soils in surface but at deeper, total $\mathrm{N}$ was similar in both soils. Olsen P (mg/kg) was higher with underground water irrigated soil at $0-5 \mathrm{~cm}$ depth but at $5-100 \mathrm{~cm}$ soils profile, it was higher with waste water irrigated rice soils. Micronutrients $(\mathrm{Zn}, \mathrm{Fe}, \mathrm{Cu}$ and $\mathrm{Mn})$ and heavy metals $(\mathrm{Pb}, \mathrm{Cd}, \mathrm{Ni}$ and $\mathrm{Cr})$ in soils were increased significantly through irrigation with waste water in rice-rice cropping pattern.
\end{abstract}

Key words: Long-term, soil chemical properties, industrial waste, rice.

\section{Introduction}

The Industrial wastes and effluents have increased sharply in recent years in Bangladesh. Neighboring farmers of industrial areas grow rice in their field by using industrial waste water in many years. Most of the industries in Bangladesh seldom pass the effluent through water treatment plant, as a result, untreated industrial waste water flood the land, most rice fields and surroundings the industries. Application of untreated waste water to irrigated rice fields is raising concern about possible health risks associated with the consumption of rice grain [1]. Albeit industrial waste water contains some plant nutrients that may enhance the growth of crop plants, toxic metals content in them may suppress plant growth severely. Toxic metals in waste water contaminate the soil environment and also change the soil chemical properties like $\mathrm{pH}, \mathrm{EC}$, soil

Corresponding author: Rafiqul Islam, Ph.D., research field: soil science. organic matter, primary, secondary nutrient elements including heavy metals [2]. Begum, R. A. [3] expressed her concern about the accumulation of heavy metal in the agricultural soils of Bangladesh. Industrial effluents have been pointed out as the main source of toxic metals both for plant and soils [4, 5]. Among such metals, cadmium and zinc are notoriously mobile and likely to move down through the soil profile to contaminate ground water, even though they are easily intercepted by clay particles in subsurface horizons [6, 7]. Seneviratne, N. M. G. [8] reported that controlled application of rubber effluent on land caused changes in soil properties and improved in soil water retention while Lim, C. A. [9] recorded increase in $\mathrm{pH}, \mathrm{Ca}, \mathrm{Mg}$ and organic matter content with the application of palm oil mill effluent. Valdes, E. observed an increase in soil organic matter by $1 \%$ with sugar factory effluent applied to soils in Cuba taking into account the deficiency in the humic matter of the soil. During last decade, the unique agroecological conditions of 
rice soils resulting from their input intensity, intensive rice cover, soil and hydrological characteristics and spatial variability have raised considerable research interest [11-13]. This is especially so considerable in developing countries where treatment of waste waters is limited, thus raising concern about heavy metals contamination of these soils when irrigated with untreated waste water and subsequent accumulation in food chain through plant uptake. In view of the above, this study aimed at determining the vertical distribution of soil chemical properties under waste water irrigated rice field.

\section{Materials and Methods}

Soil samples were collected from Mouchak area (Madhpur tract, Agro Ecological Zone (AEZ) 28) of

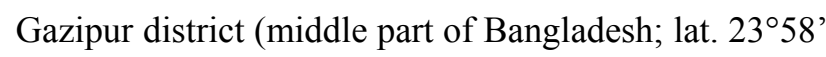
$\mathrm{N}$, long. $90^{\circ} 23^{\prime}$ E, $30 \mathrm{~m}$ above mean sea level) which has a long cropping history under rice-rice systems. The average temperature ranges from $8.2{ }^{\circ} \mathrm{C}$ in winter to $36.6{ }^{\circ} \mathrm{C}$ in summer. The mean annual rainfall is about $2,000 \mathrm{~mm}$. The sampling area represents two kinds of farmers' managed rice fields: (i) irrigated with underground Fresh Water (FW) and (ii) irrigated with Industrial Waste Water (IWW) for 8-10 years. The distance between FW and IWW irrigated field were 500 meters.

\subsection{Soil Collection}

Profile sampling in December 2010 was done up to $100 \mathrm{~cm}$ depth in a sequence of $0-5 \mathrm{~cm}, 5-10 \mathrm{~cm}, 10-15$ $\mathrm{cm}, 15-30 \mathrm{~cm}, 30-50 \mathrm{~cm}$ and $50-100 \mathrm{~cm}$, respectively. The samples were collected with the help of knife from all the side of the pit and the collected samples were composite to make about $1 \mathrm{~kg}$. The collected samples were brought Soil Science Division green house of BRRI, air-dried, crushed and sieved through $2 \mathrm{~mm}$ sieve prior to analysis. Soil $\mathrm{pH}\left(\mathrm{pH}_{\mathrm{W}}, \mathrm{pH}_{\mathrm{KCl}}\right.$ and $\Delta \mathrm{pH})$, Electrical Conductivity (EC) $(\mathrm{dS} / \mathrm{m})$, organic carbon (\%), total $\mathrm{N}(\%)$, Olsen $\mathrm{P}(\mathrm{mg} / \mathrm{kg})$, exchangeable cations ( $\mathrm{Ca}, \mathrm{Mg}, \mathrm{K}$ and $\mathrm{Na})(\mathrm{cmol} / \mathrm{kg})$, trace elements $(\mathrm{Zn}, \mathrm{Fe}, \mathrm{Mn}$ and $\mathrm{Cu})(\mathrm{mg} / \mathrm{kg})$ and heavy metals $(\mathrm{Pb}, \mathrm{Cd}, \mathrm{Cr}$ and $\mathrm{Ni})(\mathrm{mg} / \mathrm{kg})$ were determined from the samples. Details analytical methods that were used for soil analyses have been shown in Table 1.

Table 1 Details analytical methods that were used for soil samples analysis.

\begin{tabular}{|c|c|}
\hline Soil property & Method \\
\hline $\mathrm{pH}_{\mathrm{W}}$ & $\begin{array}{l}\text { 1:2.5 soil water ratio, using glass electrode method [14]. Ten g of air dried soil sample was taken in a } 50 \mathrm{~mL} \\
\text { of beaker and } 25 \mathrm{~mL} \text { of distilled water was added. The suspension was stirred with a glass-rod at regular } \\
\text { interval for } 30 \text { minutes. A glass electrode } \mathrm{pH} \text { meter (WPA Linton Cambridge, UK) calibrated with buffer } \mathrm{pH} \\
7.0 \text { and } 4.0 \text { measured the pH of the soil suspension. }\end{array}$ \\
\hline $\mathrm{pH}(\mathrm{KCl})$ & $\begin{array}{l}\text { The } \mathrm{pH}_{\mathrm{KCl}} \text { was determined by stirring } 10 \mathrm{~g} \text { soil in } 25 \mathrm{~mL} 1.0 \mathrm{M} \mathrm{KCl} \text { solution in a similar manner of } \mathrm{pH} \\
\left(\mathrm{H}_{2} \mathrm{O}\right) \text { determination. }\end{array}$ \\
\hline Delta $\mathrm{pH}(\Delta \mathrm{pH})$ & The difference between the $\mathrm{pH}$ in $\mathrm{KCl}$ and that in water gave the value of $\Delta \mathrm{pH}$, as $\Delta \mathrm{pH}=\mathrm{pH}_{\mathrm{KCl}}-\mathrm{pH}\left(\mathrm{H}_{2} \mathrm{O}\right)$. \\
\hline $\begin{array}{l}\text { Electrical conductivity } \\
(\mathrm{dS} / \mathrm{m})\end{array}$ & $\begin{array}{l}\text { A portion of } 20 \mathrm{gm} \text { of air dried soil sample was taken in a } 250 \mathrm{~mL} \text { of conical flask and then } 100 \mathrm{~mL} \text { of } \\
\text { distilled water was added. It was shaken for } 30 \text { minutes and filtered through Whatman \# } 42 \text { filter paper. } \\
\text { Electrical conductivity was measured from filtered sample using conductivity meter (YSI Model 32, [14]). }\end{array}$ \\
\hline Organic carbon $(\%)$ & $\begin{array}{l}\text { Walkley and Black wet digestion method [15] was followed to determine organic carbon. The sieved soil } \\
\text { was again passed through } 0.5 \mathrm{~mm} \text { sieve to determine organic carbon. One gm soil sample was taken in a } 500 \\
\text { mL conical flask, and then } 10 \mathrm{~mL} \text { of } 1 \mathrm{~N} \mathrm{~K}_{2} \mathrm{Cr}_{2} \mathrm{O}_{7} \text { solution and } 20 \mathrm{~mL} \text { of conc. } \mathrm{H}_{2} \mathrm{SO}_{4} \text { was added. Flask was } \\
\text { then kept for } 30 \text { minutes for completion of oxidation. Then } 200 \mathrm{~mL} \text { of distilled water, } 10 \mathrm{~mL} \text { of } \mathrm{H}_{3} \mathrm{P}_{4} \text { and } 2 \\
\text { mL of di-phenyl amine indicator solution were added. The sample was then titrated with } 1 \mathrm{~N} \mathrm{FeSO}_{4} \text { solution } \\
\text { until green color was appeared. A blank sample was also taken to calculate the results. }\end{array}$ \\
\hline Total N (\%) & $\begin{array}{l}\text { Modified Kjeldahl method [16] was followed to determine total } \mathrm{N} \text {. One gm air-dried and } 0.5 \mathrm{~mm} \text { sieve soil } \\
\text { was taken in a Kjeldahl flask, and then digested using } 2 \mathrm{~g} \text { of salt mixture }\left(\mathrm{K}_{2} \mathrm{SO}_{4}+\mathrm{CuSO}_{4}\right) \text { and } 5-7 \mathrm{~mL} \text { conc. } \\
\mathrm{H}_{2} \mathrm{SO}_{4} \text { until the acid soil mixture turns white. After cooling the digest, } 10 \mathrm{~mL} 4 \% \mathrm{H}_{3} \mathrm{BO}_{3} \text { and } 2-4 \text { drops of } \\
\text { mixed indicator was taken in a } 125 \mathrm{~mL} \text { conical flask and placed under the condenser. Then the whole digest } \\
\text { was transferred into distillation flask by washing with distilled water and added } 20 \mathrm{~mL} \text { of } 40 \% \mathrm{NaOH} \text {. } \\
\text { Absolute } 40-50 \mathrm{~mL} \text { distillate was collected and titrated the distillate against the } 0.05 \mathrm{~N} \mathrm{H}_{2} \mathrm{SO}_{4} \text {. A blank } \\
\text { sample was also taken simultaneously to calculate the results. }\end{array}$ \\
\hline
\end{tabular}


Table 1 continued

\begin{tabular}{|c|c|}
\hline Soil property & Method \\
\hline Olsen P (mg/kg) & $\begin{array}{l}\text { Olsen method [17] was followed to determine available P. A portion of } 2.5 \mathrm{gm} \text { of air dried soil sample was } \\
\text { taken in a } 125 \mathrm{~mL} \text { of conical flask and then } 25 \mathrm{~mL} \text { of extracting solution }(0.5 \mathrm{M} \mathrm{NaHCO} \text {, pH } 8.5) \text { was } \\
\text { added. It was shaken for } 30 \text { minutes and filtered through Whatman } \# 42 \text { filter paper. A portion of } 2 \mathrm{~mL} \text { of } \\
\text { aliquot was taken into } 25 \mathrm{~mL} \text { test tube. Exactly } 6 \mathrm{~mL} \text { of distilled water and } 2 \mathrm{~mL} \text { of color reagent was added. } \\
\text { The color reagent was prepared following [19]. Finally water was added to make volume up to the mark } \\
(10 \mathrm{~mL}) \text {. Reading was through Spectrophotometer at } 710 \mathrm{~nm} \text { wavelength. }\end{array}$ \\
\hline $\begin{array}{l}\text { Exchangeable } \mathrm{Ca}, \mathrm{Mg}, \\
\mathrm{K} \text { and } \mathrm{Na}(\mathrm{cmol} / \mathrm{kg})\end{array}$ & $\begin{array}{l}\text { Thomas, G. W. [19] method was followed to determine exchangeable cations. A portion of ten gm of air } \\
\text { dried sieved soil sample was taken in a } 125 \mathrm{~mL} \text { of conical flask, then } 50 \mathrm{~mL} \text { of extracting solution }(1 \mathrm{~N} \\
\mathrm{CH}_{3} \mathrm{COONH}_{4} \text {, pH 7.0) was added. It was shaken for } 10 \text { minutes and filtered through Whatman \# } 42 \text { filter } \\
\text { paper. Incase of exchangeable } \mathrm{K} \text { and Na direct reading was taken from atomic absorption spectrophotometer } \\
\text { at } 766.5 \mathrm{~nm} \text { and } 589 \mathrm{~nm} \text { wavelengths, respectively. For Exchangeable Ca was determined by diluting a } \\
\text { portion of } 2 \mathrm{~mL} \text { of aliquot with } 1 \mathrm{~mL} \text { of } \mathrm{La}_{2} \mathrm{O}_{3} \text { and } 7 \mathrm{~mL} \text { of distilled water into } 25 \mathrm{~mL} \text { test tube and atomic } \\
\text { absorption Spectrophotometer reading was taken at } 422.7 \mathrm{~nm} \text { wavelength. For } \mathrm{Mg}, 1 \mathrm{~mL} \text { aliquot was diluted } \\
\text { in } 19 \mathrm{~mL} \text { of distilled water into } 25 \mathrm{~mL} \text { test tube and atomic absorption Spectrophotometer reading was taken } \\
\text { at } 285.2 \mathrm{~nm} \text { wavelength. }\end{array}$ \\
\hline $\begin{array}{l}\text { Trace elements } \\
(\mathrm{Zn}, \mathrm{Fe}, \mathrm{Mn} \text { and } \mathrm{Cu}) \\
(\mathrm{mg} / \mathrm{kg})\end{array}$ & $\begin{array}{l}\text { Lindsay, W. L. [20] method was followed to determine trace elements. A portion of ten gm of air dried } \\
\text { sieved soil sample was taken in a } 125 \mathrm{~mL} \text { of conical flask, then } 20 \mathrm{~mL} \text { of extracting solution } \\
\text { (EDTA-Ethylene Diamine Teteraacetic Acid) was added. It was shaken for } 2 \text { hours and filtered through } \\
\text { Whatman \# } 42 \text { filter paper. Concentrations of } \mathrm{Zn}, \mathrm{Fe}, \mathrm{Mn} \text { and } \mathrm{Cu} \text { were determined by atomic absorption } \\
\text { Spectrophotometer with respective wavelength. }\end{array}$ \\
\hline $\begin{array}{l}\text { Heavy metals }(\mathrm{Pb}, \mathrm{Cd}, \\
\mathrm{Cr} \text { and } \mathrm{Ni})(\mathrm{mg} / \mathrm{kg})\end{array}$ & $\begin{array}{l}\text { Heavy metals analysis involved digestion of } 0.5 \mathrm{~g} \text { of soil sample with concentrated } \mathrm{HNO}_{3} \text { and } \mathrm{HClO}_{4}(5: 2) \\
\text { at } 120^{\circ} \mathrm{C} \text { following the procedure described by Lindsay, W. L. [20]. Finally, the digest was filtered through } \\
\text { Whatman \# } 42 \text { filter paper and diluted to } 50 \mathrm{~mL} \text { with distilled water prior to analysis. Concentrations of } \mathrm{Pb} \text {, } \\
\mathrm{Cd}, \mathrm{Cr} \text { and Ni were determined by atomic absorption spectrophotometer with respective wavelength (AAS, } \\
\text { Model, Varian 55B). }\end{array}$ \\
\hline
\end{tabular}

\section{Results and Discussion}

\subsection{Soil $p H$}

The control soils showed $\mathrm{pH}_{\mathrm{W}}$ less than 5.0 at $0-30$ $\mathrm{cm}$ depth that was much lower than the IWW soils (Fig. 1). The IWW soil had $\mathrm{pH}_{\mathrm{W}}$ of 5.76 compared to 4.60 in FW soil at $0-5 \mathrm{~cm}$ depth. At $5-10 \mathrm{~cm}$ depth, the IWW soil increased $\mathrm{pH}_{\mathrm{W}}$ to 6.60 compared to 4.70 in the FW soil. The difference in $\mathrm{pH}_{\mathrm{W}}$ between $\mathrm{FW}$ and IWW soils exist throughout the soil profiles. At 15-30 cm depth, IWW soil showed about 1 unit higher $\mathrm{pH}_{\mathrm{W}}$ than that of $\mathrm{FW}$ soil. At deeper profile, the difference was narrower. The increase in soil $\mathrm{pH}_{\mathrm{W}}$ and decrease in exchangeable acidity is attributed to the higher calcium and magnesium ions accumulated in waste water irrigated rice field. This report was similar to findings of Poon, Y. C., [21] and Seneviratne, N. M. G. [8] with palm oil mill and rubber effluent irrigated soils, respectively.

The $\mathrm{pH}_{\mathrm{KCl}}$ profile was similar with IWW soils but slightly different in $\mathrm{FW}$ soils from $\mathrm{pH}_{\mathrm{W}}$ profile at deeper soil depth (Fig. 2). Starting from 0-15 cm soil depth, the $\mathrm{pH}_{\mathrm{KCl}}$ of $\mathrm{FW}$ soils were more or less similar with $\mathrm{pH}_{\mathrm{W}}$ but at deeper soil depth, the $\mathrm{pH}_{\mathrm{KCl}}$ was progressively decreased. The $\mathrm{pH}_{\mathrm{KCl}}$ of IWW soil was 4.77 compared to 3.90 in FW soil at $0-5 \mathrm{~cm}$ depth. At 5-10 cm depth, the IWW soil increased $\mathrm{pH}_{\mathrm{KCl}}$ to 5.38 compared to 3.94 in $\mathrm{FW}$ soil. The difference in $\mathrm{pH}_{\mathrm{KCl}}$ between control and IWW fields exist throughout the soil profiles. However, the difference was more prominent in surface but at deeper profile the difference was narrower.

The difference in $\mathrm{pH}_{\mathrm{w}}$ and $\mathrm{pH}_{\mathrm{KCl}}$ between $\mathrm{FW}$ and IWW rice field in surface soil profile may be attributed to the previous management, but in deeper depth, the difference in soil acidity may be due to difference in soil inherent properties.

\subsection{Delta $p H(\Delta p H)$}

Delta $\mathrm{pH}$ of soil gives a good indication of the charge characteristics of soil colloids. A positive value for $\Delta \mathrm{pH}$ indicates the net charge associated with the soil colloids was positive, likewise a negative values for $\Delta \mathrm{pH}$ announces the negative charged colloids in 


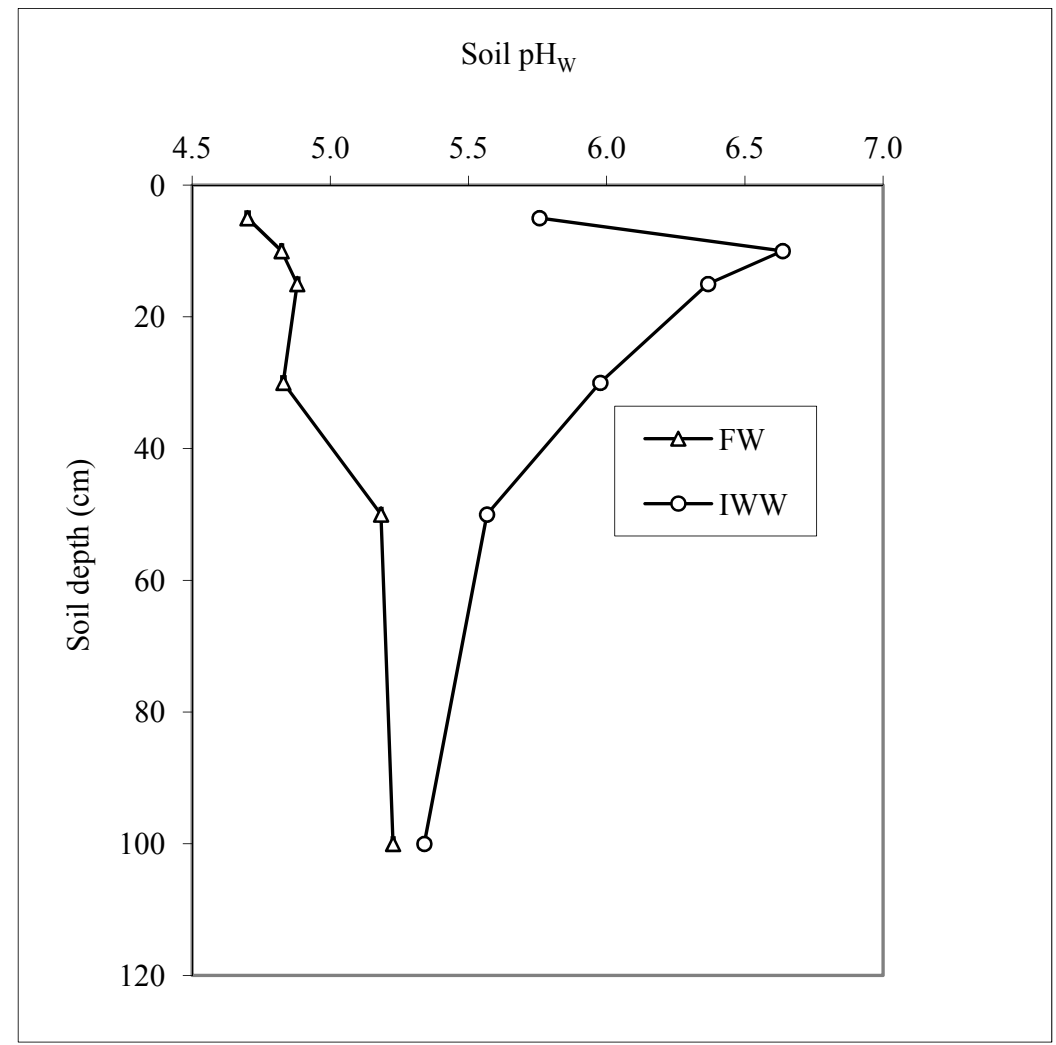

Fig. 1 Distribution of $\mathrm{pH}_{\mathrm{W}}$ in soil profiles of industrial effluents contaminated and uncontaminated soils.

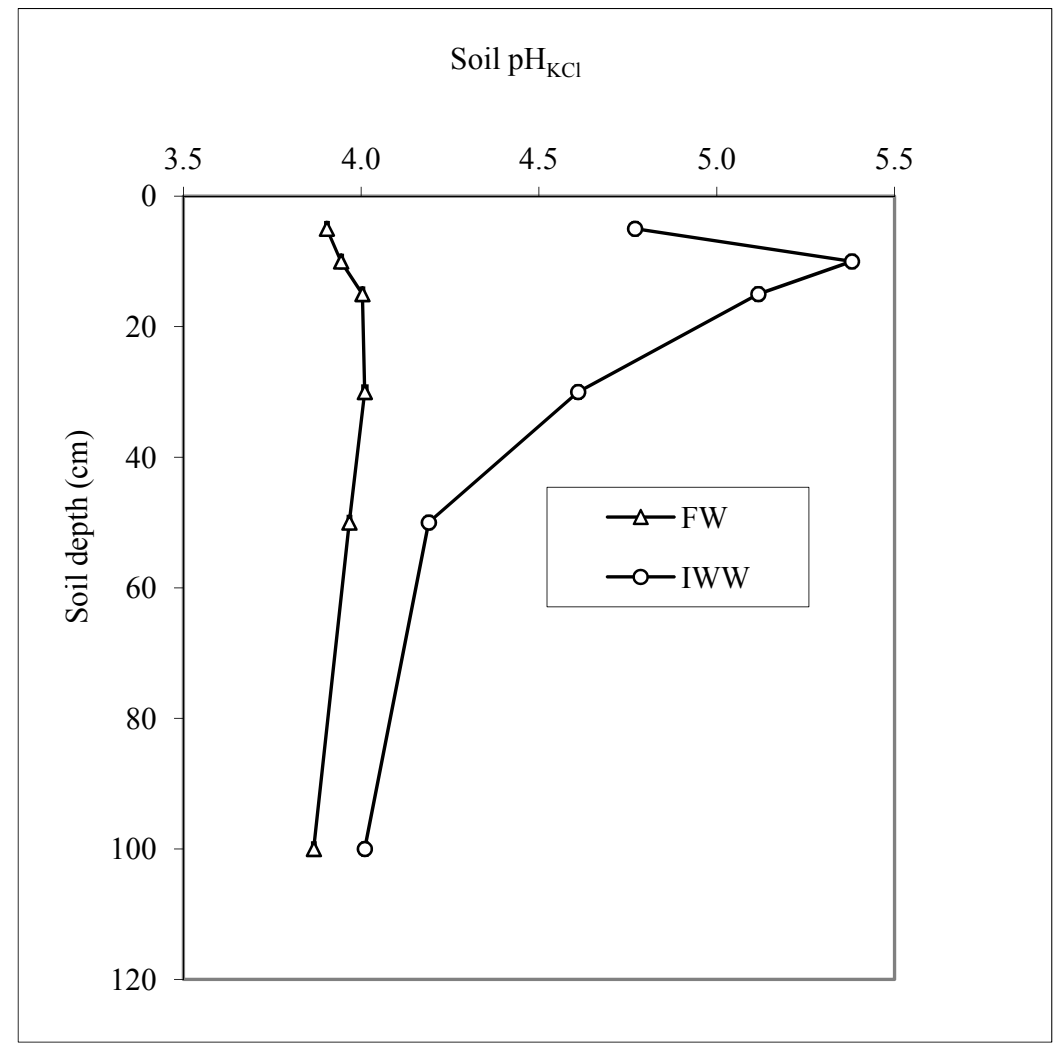

Fig. 2 Distribution of $\mathrm{pH}_{\mathrm{KCl}}$ in soil profiles of industrial effluents contaminated and uncontaminated soils. 


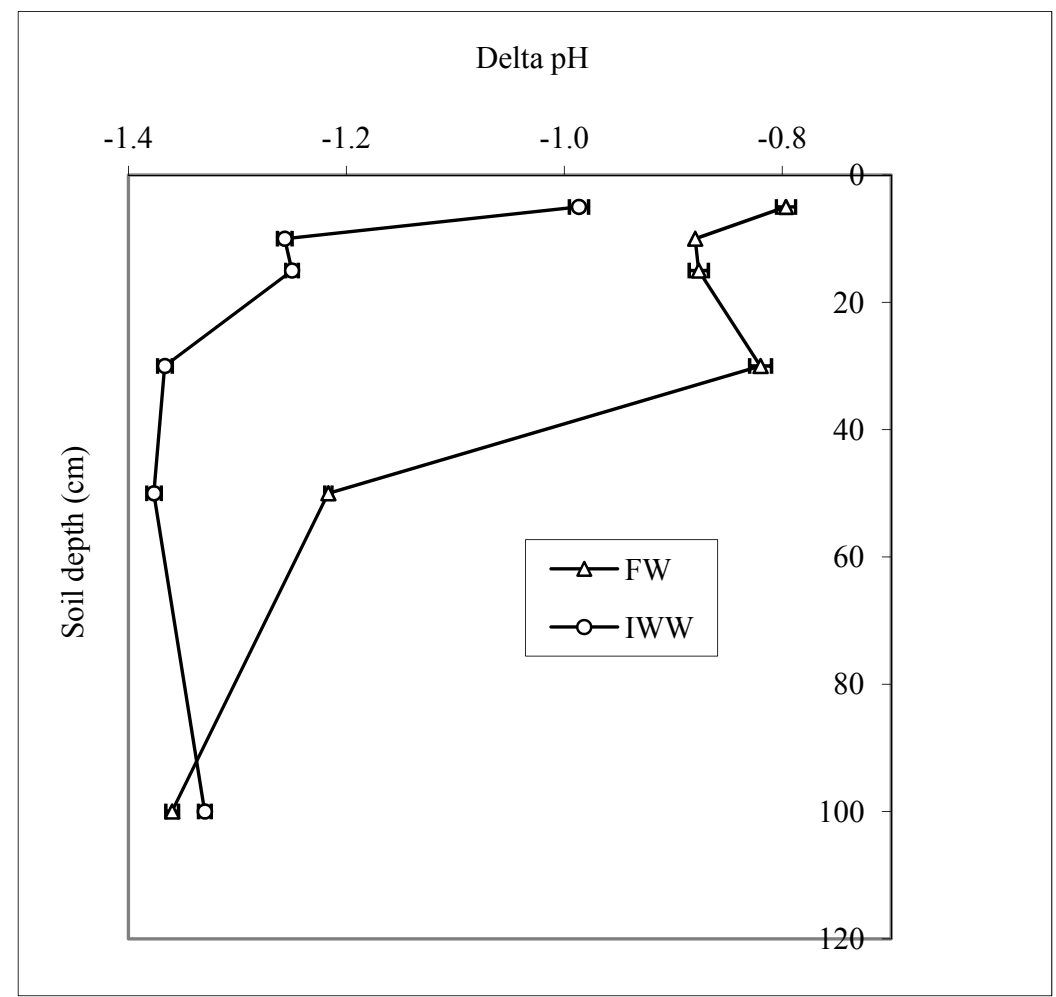

Fig. 3 Distribution of $\Delta \mathrm{pH}$ in soil profiles of industrial effluents contaminated and uncontaminated soils.

soil. The surface charge of both the soils was considerably negative (Fig. 3). Relatively more negative charges developed with IWW soils than that of FW soils due to adsorption of acidic ions. Industrial waste water irrigated soils developed 0.19 units and 0.37 units more negative charge than that of FW soils at $0-5 \mathrm{~cm}$ and $5-10 \mathrm{~cm}$ soil depth, respectively. At $10-15 \mathrm{~cm}$ depth, both the soils had the similar negative charge to that of $5-10 \mathrm{~cm}$ soils. The IWW soils showed an increase in $\Delta \mathrm{pH}$ than the FW soil by 0.55 units and 0.16 units at $15-30 \mathrm{~cm}$ and $30-50 \mathrm{~cm}$ depth, respectively. At deeper depth (50-100 cm), IWW and FW soils gave almost the similar $\Delta \mathrm{pH}$.

\subsection{Electrical Conductivity (EC)}

At $0-5 \mathrm{~cm}$ soil depth, EC of IWW soil was 6.85 $\mathrm{dS} / \mathrm{m}$ but in $\mathrm{FW}$ soil, it was $1.53 \mathrm{dS} / \mathrm{m}$. At $5-10 \mathrm{~cm}$ depth, IWW soil had 5 folds higher EC than that of FW. At 10-15 cm depth soils, it had the similar EC value to that of $5-10 \mathrm{~cm}$ depth soils. The IWW soils showed an increase in EC than the FW soils by 1.97 $\mathrm{dS} / \mathrm{m}, 1.23 \mathrm{dS} / \mathrm{m}$ and $1.60 \mathrm{dS} / \mathrm{m}$ at $15-30 \mathrm{~cm}, 30-50$ $\mathrm{cm}$ and 50-100 $\mathrm{cm}$ depth, respectively. The EC value was progressively decreased with increasing in soil depth. But above $50 \mathrm{~cm}$ soil profile, EC value was slightly increased with IWW soil. The difference in EC between FW and IWW soils exist throughout the soil profiles. The EC difference was more prominent in surface but at deeper profile, the difference was relatively narrower. Throughout the soil profile, a tremendous increase in EC was found with IWW soils than the FW soils, which may be due to enriched IWW soils with different salts specially $\mathrm{Na}$ and heavy metals (Fig. 4). These findings are good in agreement with the findings of Begum, R. A. [3] and Saif, M. S. [22].

\subsection{Organic Carbon (OC)}

The organic carbon content (\%) started to decrease sharply with the increase in soil depth (Fig. 5). In all the soil depth, OC content relatively higher with IWW soil than FW soil. The OC content of IWW soil was at $5-10 \mathrm{~cm}$ depth, the IWW soil decreased OC content to $1.19 \%$ compared to $1.03 \%$ in $\mathrm{FW}$ soil. 


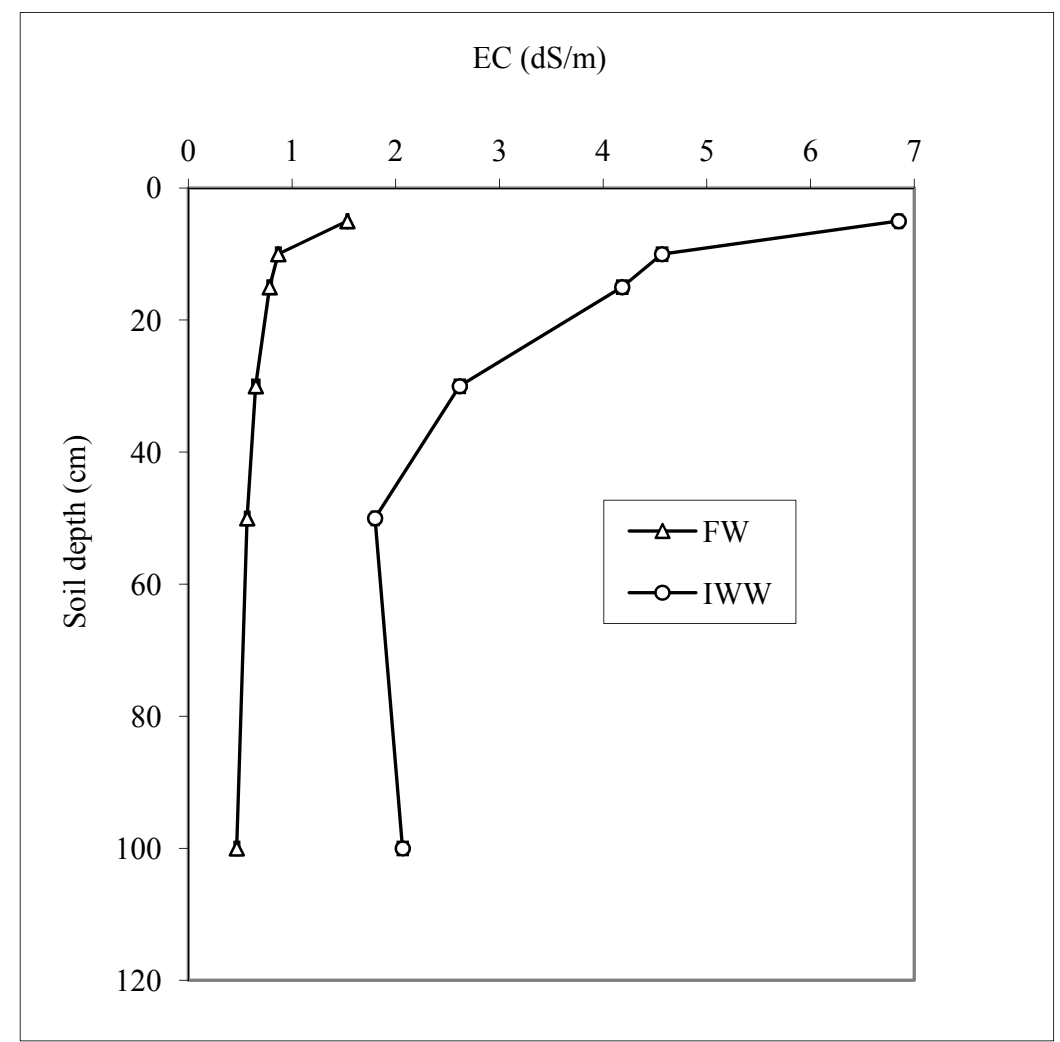

Fig. 4 Distribution of EC in soil profiles of industrial effluents contaminated and uncontaminated soils.

From $15-50 \mathrm{~cm}$ soil depths, the OC content in both the soils were more or less similar. At 50-100 cm depth, IWW soil had $0.07 \%$ higher OC content than the FW soil. The greater concentration of organic carbon content in surface soil compared to sub-surface soil may be due to accumulation organic residues left out in former. Sood, R. D. [23] earlier reported that the organic carbon content decreased with the depth of soils in Himachalpradesh of India. However, OC content was found higher with IWW soils than the FW soils. The increased OC in IWW soils as a result of high total solid present in the effluent, which may be mineralized while the decrease in $\mathrm{C} / \mathrm{N}$ ratio may be due to the occurrence of high microorganisms' activities, which assisted in the reduction of the $\mathrm{C} / \mathrm{N}$ ratio. For 1-3 years, effluents irrigation increased soil total organic carbon [2].

\subsection{Total Nitrogen}

At $0-10 \mathrm{~cm}$ soil profile, total nitrogen (\%) was higher with FW soils than that of IWW soils (Fig. 6). At $0-5 \mathrm{~cm}$ depth, FW soil had the total nitrogen of $0.19 \%$ as compared to $0.16 \%$ in IWW soil. At $5-10$ $\mathrm{cm}$ depth, FW soil decreased total nitrogen to $0.16 \%$ compared to $0.14 \%$ in IWW soil. Both in the soil, the total $\mathrm{N}$ content found more or less similar at $15-30 \mathrm{~cm}$ depth. Industrial waste water irrigated soils gave $0.02 \%$ higher and $0.02 \%$ lower total $\mathrm{N}$ content than that of $\mathrm{FW}$ soils at $30-50 \mathrm{~cm}$ and $50-100 \mathrm{~cm}$ depths, respectively.

\subsection{Olsen $P$}

At 0-5 cm soil depth, the level of Olsen $\mathrm{P}$ was slightly higher in FW soil compared to IWW soil (Fig. 7). At $0-5 \mathrm{~cm}$ soil depth, FW soil gave the Olsen $P$ of $5.77 \mathrm{mg} / \mathrm{kg}$ compared to $5.03 \mathrm{mg} / \mathrm{kg}$ in IWW soil. Industrial waste irrigated soil gave $0.54 \mathrm{mg} / \mathrm{kg}$ higher $\mathrm{P}$ content than that of FW soil at $5-10 \mathrm{~cm}$ depth while at $10-15 \mathrm{~cm}$ depth, it was $0.33 \mathrm{mg} / \mathrm{kg}$ lower. At deeper soil profile (30-100 cm depth), the level of Olsen P was found considerably higher in IWW soils than that 


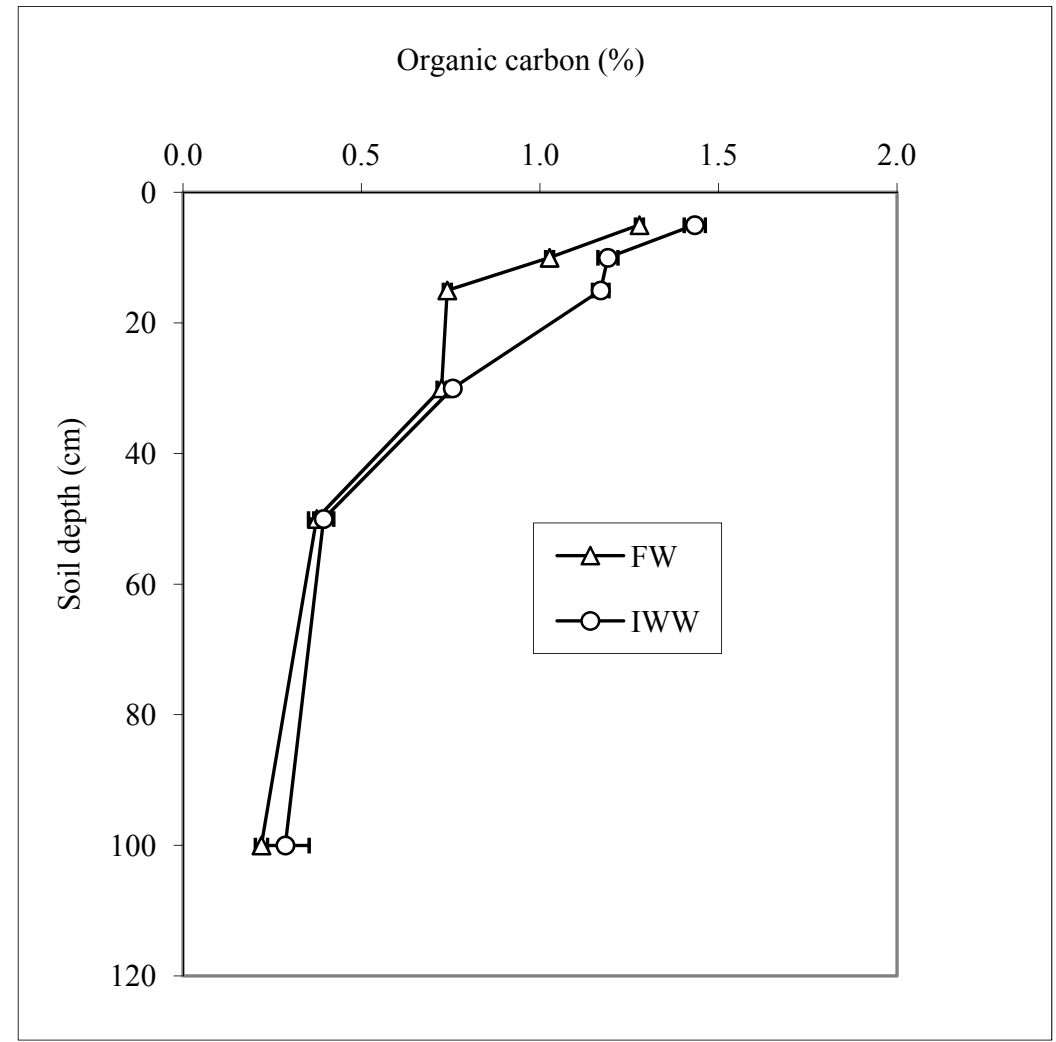

Fig. 5 Distribution of organic carbon (\%) in soil profiles of industrial effluents contaminated and uncontaminated soils.

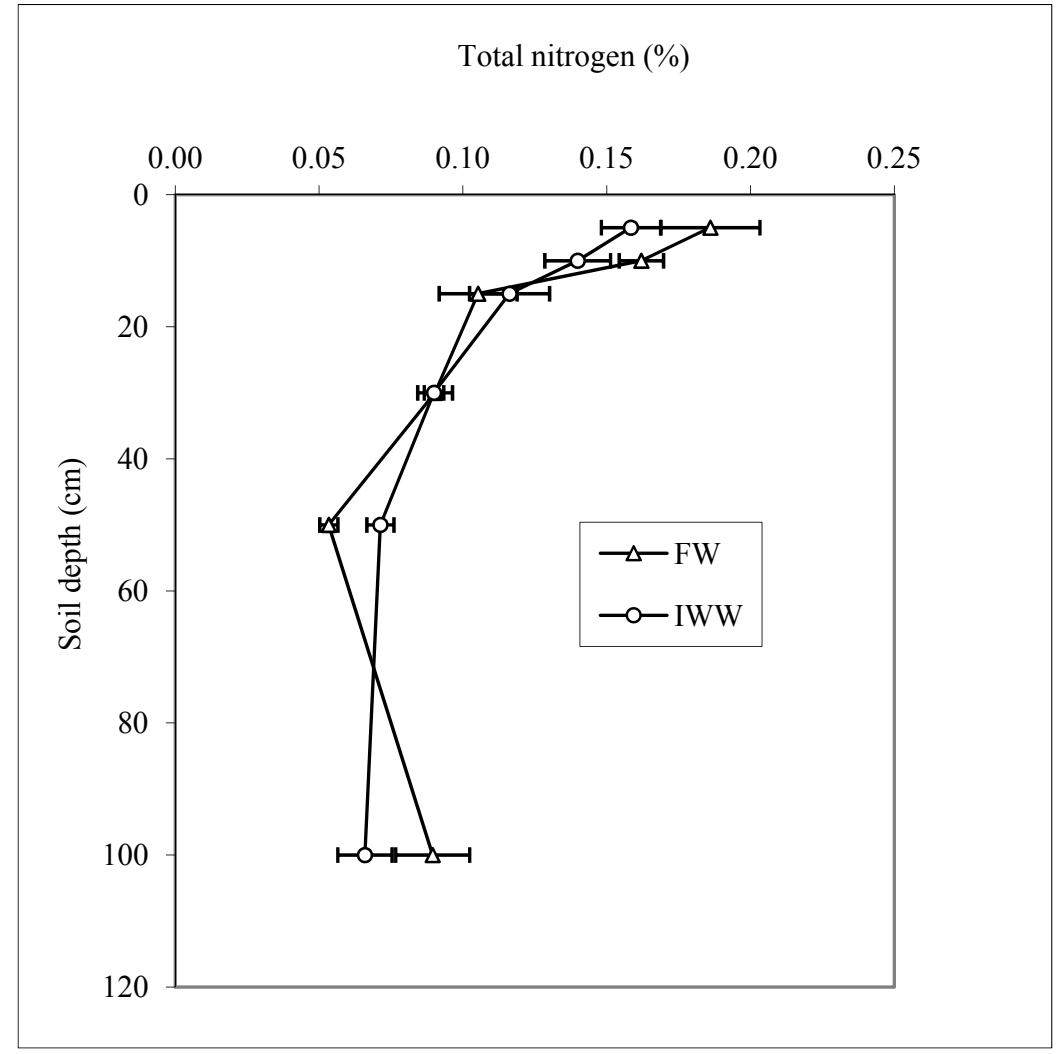

Fig. 6 Distribution of total nitrogen $(\%)$ in soil profiles of industrial effluents contaminated and uncontaminated soils. 


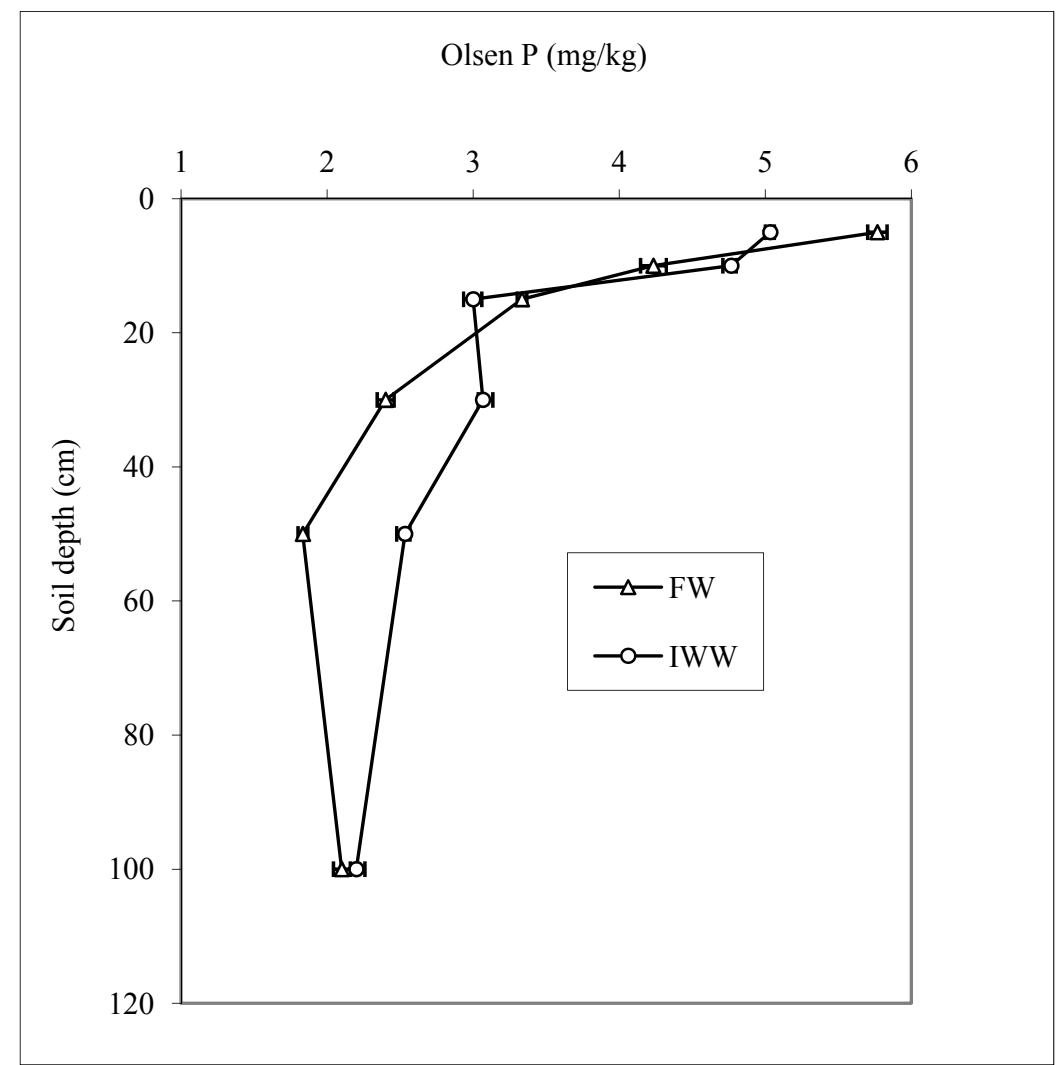

Fig.7 Distribution of Olsen $P(\mathrm{mg} / \mathrm{kg})$ in soil profiles of industrial effluents contaminated and uncontaminated soils.

of FW soils. The IWW soils showed an increase in Olsen P than the FW soils by $0.67 \mathrm{mg} / \mathrm{kg}, 0.70 \mathrm{mg} / \mathrm{kg}$ and $0.10 \mathrm{mg} / \mathrm{kg}$ at $15-30 \mathrm{~cm}, 30-50 \mathrm{~cm}$ and $50-100 \mathrm{~cm}$ depths, respectively. The higher component of $\mathrm{P}$ in the soil could be result of fixation attributed to high $\mathrm{pH}$ brought about by $\mathrm{Ca}, \mathrm{Mg}$ and $\mathrm{Na}$ in the soil. The decreasing trend of $\mathrm{P}$ profile at $0-15 \mathrm{~cm}$ depth may be attributed to the influence of rice root uptake. The depletion of Olsen P was more in FW soils than the IWW soils in deeper soil profile due to the lower soil pH value.

\subsection{Exchangeable Cations (Ca, $\mathrm{Mg}, \mathrm{K}$ and $\mathrm{Na}$ )}

In all the soil depths, the exchangeable $\mathrm{Ca}$ had considerably higher in IWW soils than that of FW soils (Fig. 8). The exchangeable $\mathrm{Ca}$ concentration varied from $3.46 \mathrm{cmol} / \mathrm{kg}$ to $6.92 \mathrm{cmol} / \mathrm{kg}$ in IWW soils but in FW soils, it was ranged from $3.06 \mathrm{cmol} / \mathrm{kg}$ to $6.21 \mathrm{cmol} / \mathrm{kg}$. Industrial waste water irrigated soils showed an increase in Ca content than the FW soils by
$0.71 \mathrm{cmol} / \mathrm{kg}, \quad 1.52 \mathrm{cmol} / \mathrm{kg}, \quad 1.20 \mathrm{cmol} / \mathrm{kg}, \quad 0.76$ $\mathrm{cmol} / \mathrm{kg}$ and $0.40 \mathrm{cmol} / \mathrm{kg}$ at $0-5 \mathrm{~cm}, 5-10 \mathrm{~cm}, 10-15$ $\mathrm{cm}, 15-30 \mathrm{~cm}$ and $30-50 \mathrm{~cm}$ depths, respectively. A tremendous increase in $\mathrm{Ca}$ content was found in the IWW soil than that of FW soil at 50-100 cm depth. The IWW soil gave 1.63 units higer $\mathrm{Ca}$ content than the FW soil at 50-100 cm depth. From 0-50 cm depth, the concentration of $\mathrm{Ca}$ decreased both in the soil but at deeper soil depth, it was increased again. It might be due to leaching related translocation. Lim, C. A. [9] recorded increase in $\mathrm{Ca}$ in soil with the application of palm oil mill effluents.

The difference in exchangeable $\mathrm{Ca}$ concentration between two soils may be explained by the difference in plant growth, uptake and accumulation.

The exchangeable $\mathrm{Mg}$ profile changed in rice soil by the waste water irrigation (Fig. 9). The exchangeable $\mathrm{Mg}$ concentration varied from 0.28 $\mathrm{cmol} / \mathrm{kg}$ to $1.07 \mathrm{cmol} / \mathrm{kg}$ in IWW soils, but in $\mathrm{FW}$ soils it was ranged between $0.47 \mathrm{cmol} / \mathrm{kg}$ and 0.90 


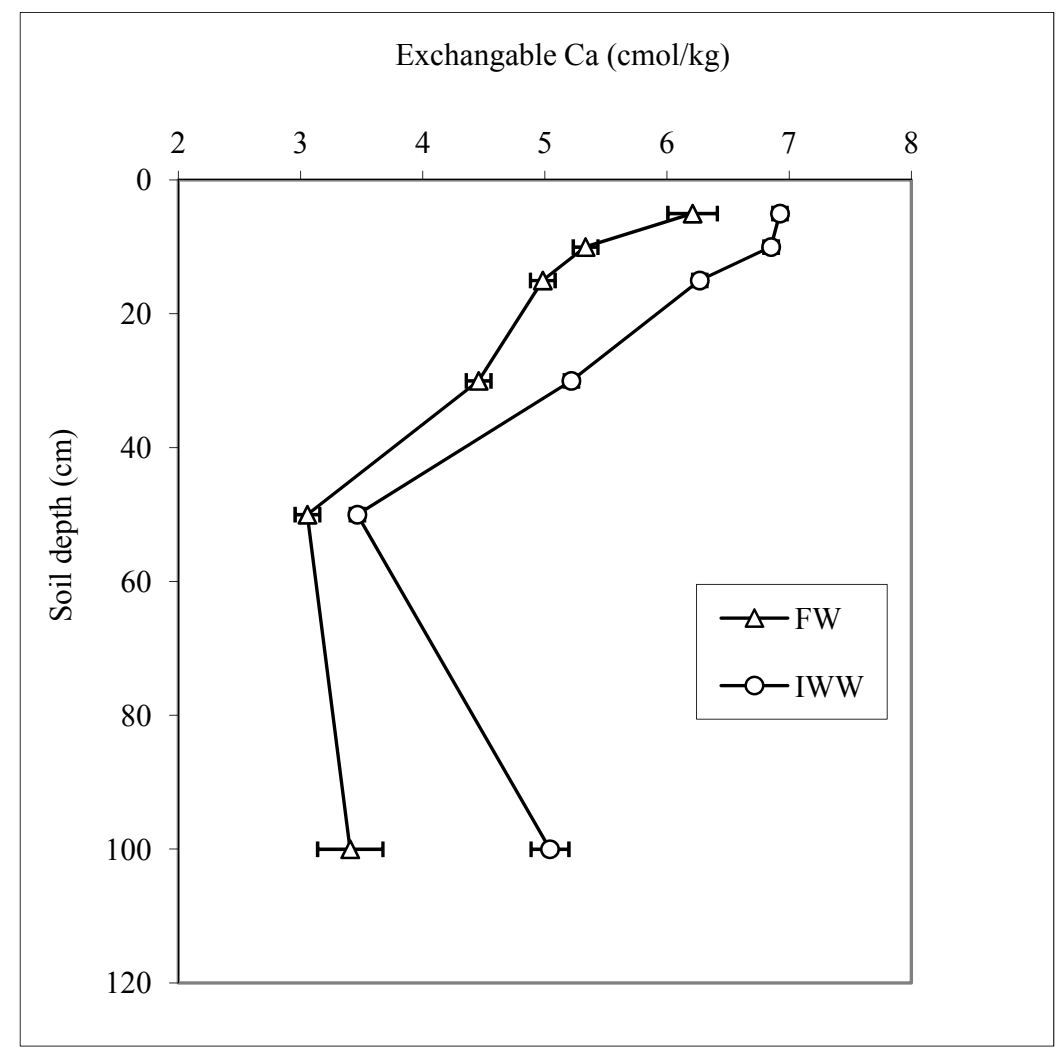

Fig. 8 Distribution of exchangeable $\mathrm{Ca}(\mathrm{cmol} / \mathrm{kg})$ in soil profiles of industrial effluents contaminated and uncontaminated soils.

$\mathrm{cmol} / \mathrm{kg}$. At 0-30 $\mathrm{cm}$ soil depth, the exchangeable $\mathrm{Mg}$ had the higher in IWW soils than that of FW soils, but at deeper profile it was higher with FW soils. The Mg concentration of IWW soils was progressively decreased with the increased in soil depth. However, in control field, the $\mathrm{Mg}$ concentration was found zigzag from 0-30 cm depth, but at deeper depth it was increased progressively. Lim, C. A. [9] recorded increase in $\mathrm{Mg}$ in surface soil with the application of palm oil mill effluent. The difference in exchangeable $\mathrm{Mg}$ concentration between two soils may be explained by the difference in plant growth, uptake and accumulation.

In all the soil depths, the exchangeable $\mathrm{K}$ had remarkably higher in IWW soils than that of FW soils (Fig. 10). The exchangeable $\mathrm{K}$ concentration varied from $0.09 \mathrm{cmol} / \mathrm{kg}$ to $0.39 \mathrm{cmol} / \mathrm{kg}$ in IWW soils but in $\mathrm{FW}$ soils, it was ranged between $0.07 \mathrm{cmol} / \mathrm{kg}$ to $0.20 \mathrm{cmol} / \mathrm{kg}$. At $0-5 \mathrm{~cm}$ depth, IWW soil had about 2 folds higher K content than the FW soil. At 5-10 cm depth, soil showed the similar exchangeable K content to that of $0-5 \mathrm{~cm}$ depth soil. Industrial waste water irrigated soils showed an increase in $\mathrm{K}$ content than the $\mathrm{FW}$ irrigated soils by $0.05 \mathrm{cmol} / \mathrm{kg}, 0.06 \mathrm{cmol} / \mathrm{kg}$, $0.02 \mathrm{cmol} / \mathrm{kg}$ and $0.01 \mathrm{cmol} / \mathrm{kg}$ at $10-15 \mathrm{~cm}, 15-30 \mathrm{~cm}$, $30-50 \mathrm{~cm}$ and $50-100 \mathrm{~cm}$ depths, respectively. In both natures of the soils, the exchangeable $\mathrm{K}$ content decreased from 0-50 $\mathrm{cm}$ depth, but above $50 \mathrm{~cm}$, the $\mathrm{K}$ content was increased. Similar result was showed by Haslbach, F. [24]. In his study, he showed the exchangeable $\mathrm{K}$ increased in the lower soil horizon. The difference in exchangeable $\mathrm{K}$ concentration between two soils may be explained by the difference in plant growth, uptake and accumulation.

The exchangeable $\mathrm{Na}$ concentrations were more prominent throughout the soil profiles with IWW soils than that of FW soils (Fig. 11). The exchangeable Na varied from $2.03 \mathrm{cmol} / \mathrm{kg}$ to $2.90 \mathrm{cmol} / \mathrm{kg}$ in IWW soils, but in $\mathrm{FW}$ soils, it was ranged from $0.53 \mathrm{cmol} / \mathrm{kg}$ to $1.01 \mathrm{cmol} / \mathrm{kg}$. Industrial waste water irrigated soils 


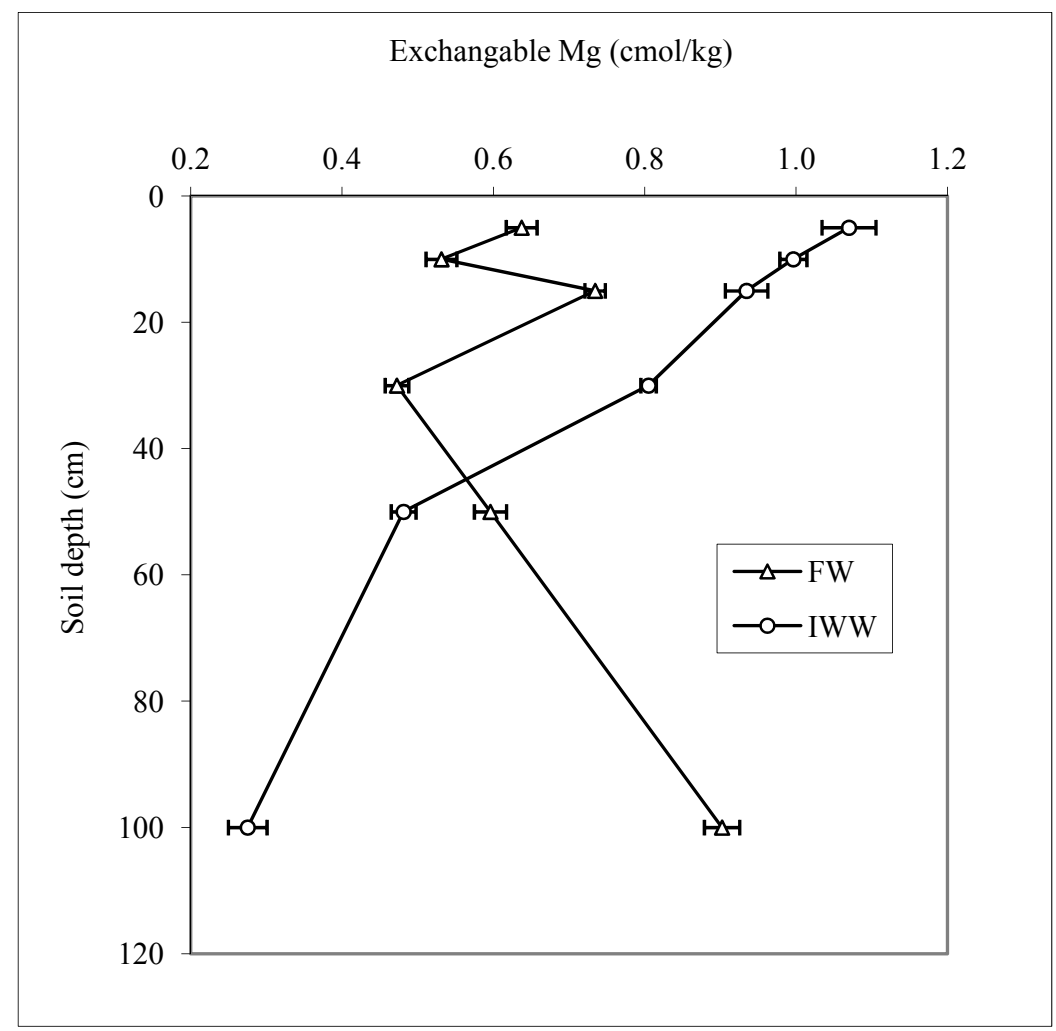

Fig. 9 Distribution of exchangeable $\mathrm{Mg}(\mathrm{cmol} / \mathrm{kg})$ in soil profiles of industrial effluents contaminated and uncontaminated soils.

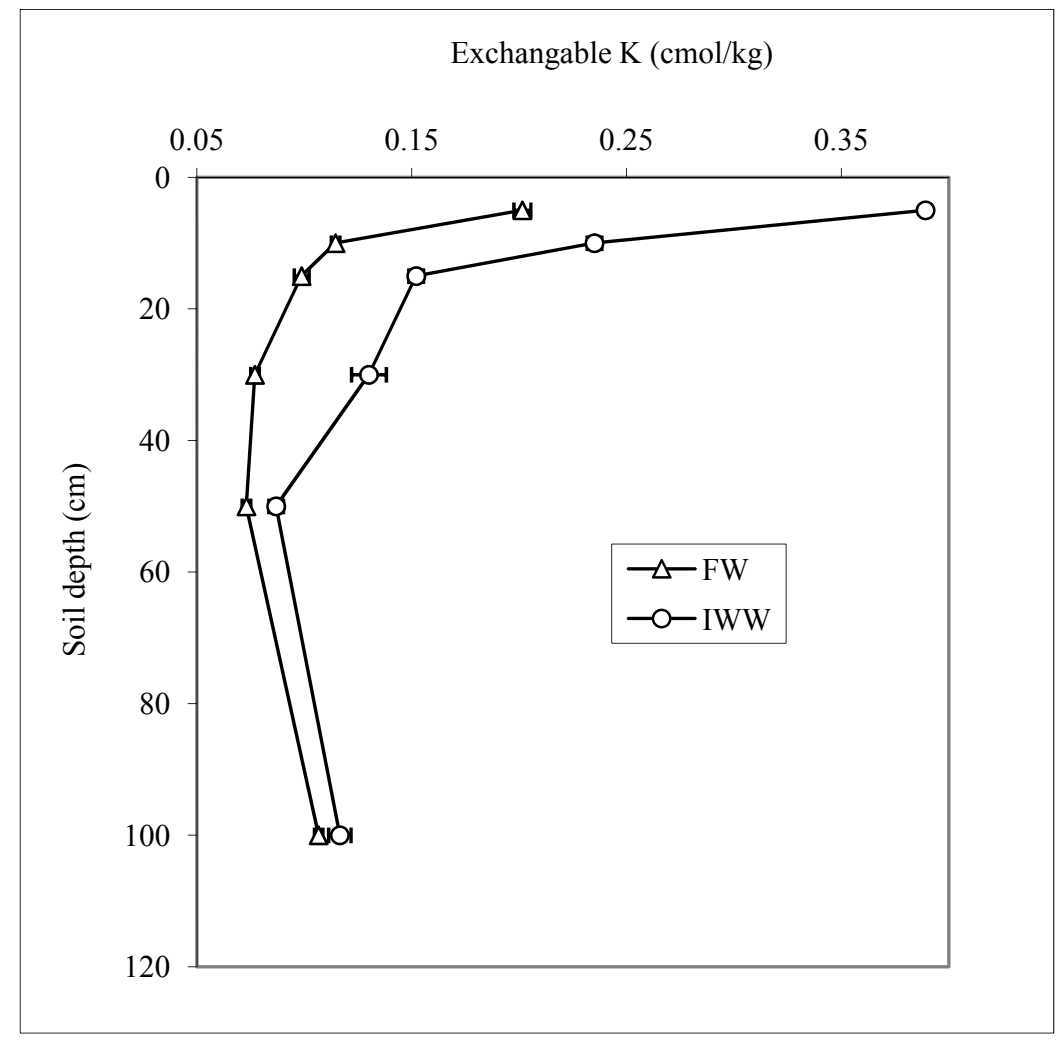

Fig. 10 Distribution of exchangeable $\mathrm{K}(\mathrm{cmol} / \mathrm{kg})$ in soil profiles of industrial effluents contaminated and uncontaminated soils. 


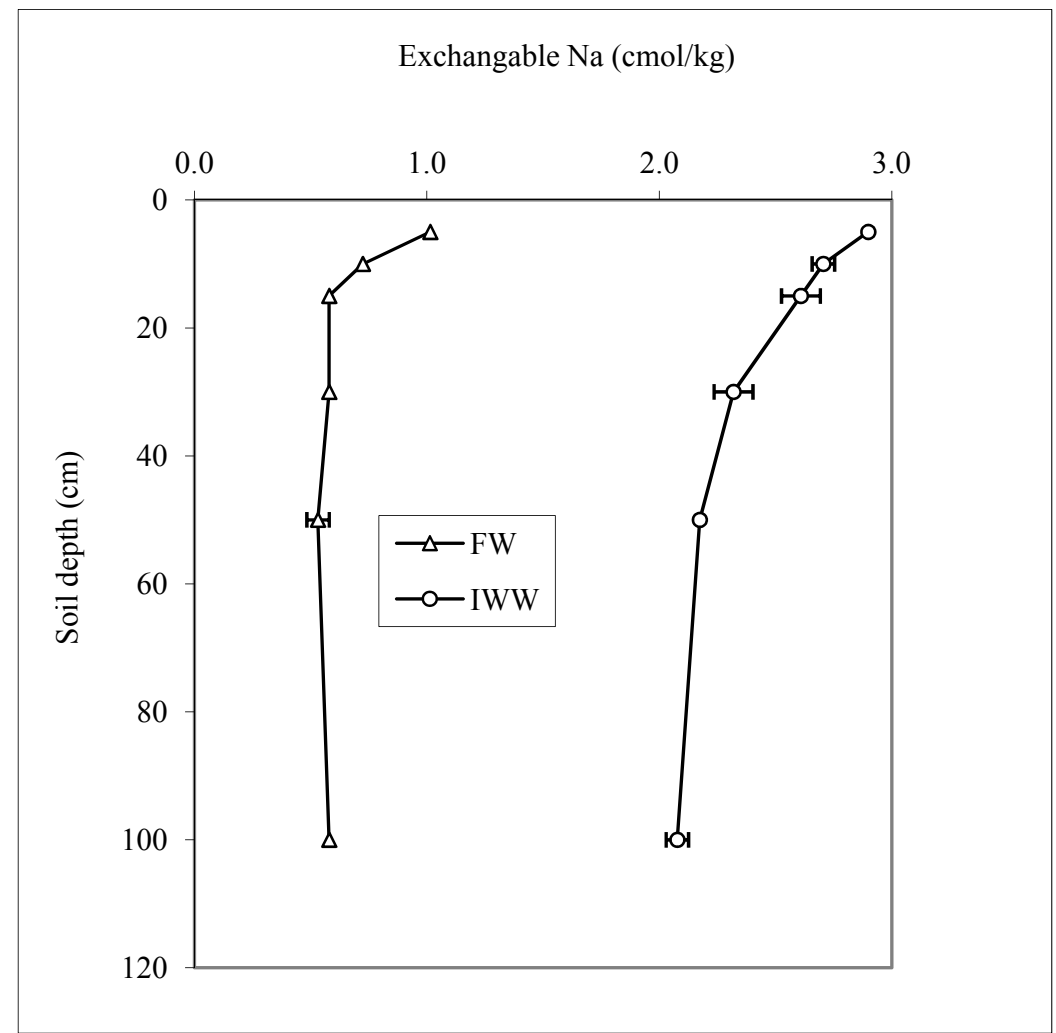

Fig. 11 Distribution of exchangeable $\mathrm{Na}(\mathrm{cmol} / \mathrm{kg})$ in soil profiles of industrial effluents contaminated and uncontaminated soils.

gave 3 folds and 4 folds higher $\mathrm{Na}$ content than that of control soils at $0-5 \mathrm{~cm}$ and $5-10 \mathrm{~cm}$ depth. At $15-30$ $\mathrm{cm}$ depth, soil had the similar Na content to that of 5-10 cm depth soil. Industrial waste water irrigated soils showed an increase in $\mathrm{Na}$ content than the FW soils by $2.03 \mathrm{cmol} / \mathrm{kg}, 1.64 \mathrm{cmol} / \mathrm{kg}$ and $1.50 \mathrm{cmol} / \mathrm{kg}$ at $10-15 \mathrm{~cm}, 30-50 \mathrm{~cm}$ and $50-100 \mathrm{~cm}$ depths, respectively. The exchangeable $\mathrm{Na}$ found higher with IWW soils than the FW soils may be due to accumulation of salt from waste water. A similar result was reported by Begum, R. A. [3].

\subsection{Trace Elements ( $\mathrm{Zn}, \mathrm{Fe}, \mathrm{Mn}$ and $\mathrm{Cu}$ )}

Industrial waste water irrigation affected the zinc content in soil profile (Fig. 12). Zinc content varied from $0.13 \mathrm{mg} / \mathrm{kg}$ to $8.64 \mathrm{mg} / \mathrm{kg}$ in IWW soils, but in FW soils it was ranged between $0.24 \mathrm{mg} / \mathrm{kg}$ to 3.53 $\mathrm{mg} / \mathrm{kg}$. Starting from $0-10 \mathrm{~cm}$ depth, a tremendous increase in $\mathrm{Zn}$ content was found in IWW soils compared to FW soils. The Zn content had $8.64 \mathrm{mg} / \mathrm{kg}$ and $5.88 \mathrm{mg} / \mathrm{kg}$ at $0-5 \mathrm{~cm}$ and $5-10 \mathrm{~cm}$ depths, respectively. The higher $\mathrm{Zn}$ content at $0-10 \mathrm{~cm}$ depth may be due to surface deposition from the waste water. At $10-15 \mathrm{~cm}$ depth, IWW soil had $0.45 \mathrm{mg} / \mathrm{kg}$ higher $\mathrm{Zn}$ content than that of FW soil. At $15-30 \mathrm{~cm}$, depth soil showed the similar result to that of $10-15 \mathrm{~cm}$ depth soil. In both the soils, the $\mathrm{Zn}$ concentration had more or less similar at 30-50 cm depth. At deeper soil depth, $\mathrm{Zn}$ concentration had $0.45 \mathrm{mg} / \mathrm{kg}$ higher in FW soil than the IWW soil. The maximum tolerable concentration of $\mathrm{Zn}$ in soil is $300 \mathrm{mg} / \mathrm{kg}$ [25]. Zinc concentration of soil in the vicinities in Bangladesh ranged from $53-477 \mathrm{mg} / \mathrm{kg}$. So, the soil profiles were suitable for crop production with respect to $\mathrm{Zn}$ content.

The available Fe profile was changed in rice soil by the IWW irrigation (Fig. 13). At 0-5 cm depth, Fe concentration was $3.28 \mathrm{mg} / \mathrm{kg}$ higher with IWW soil than that of FW soil. At $5-10 \mathrm{~cm}$ depth, FW soil showed an increase in Fe content than the IWW soil by 3.27 units. But from $15-100 \mathrm{~cm}$ soil profile, the Fe 


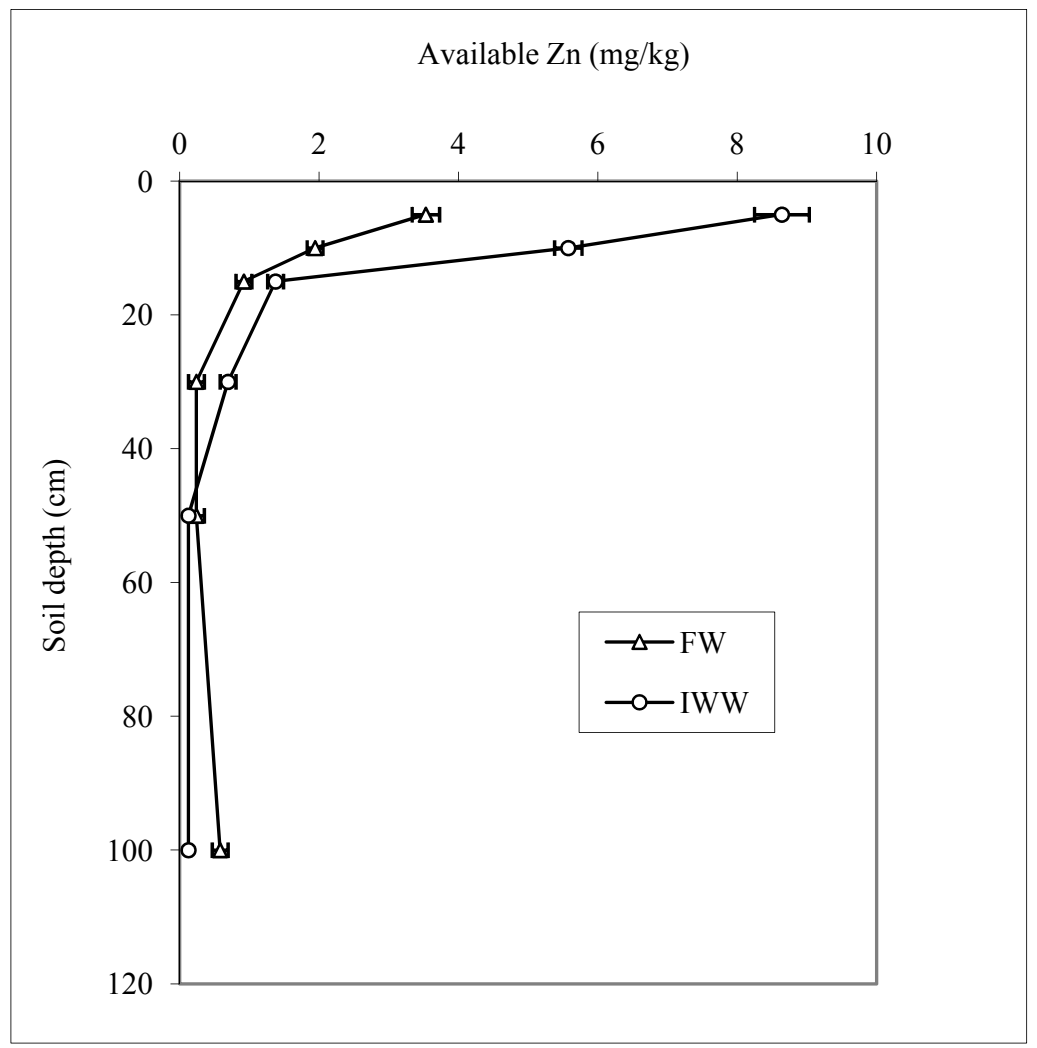

Fig. 12 Distribution of available $\mathrm{Zn}(\mathrm{mg} / \mathrm{kg})$ in soil profiles of industrial effluents contaminated and uncontaminated soils.

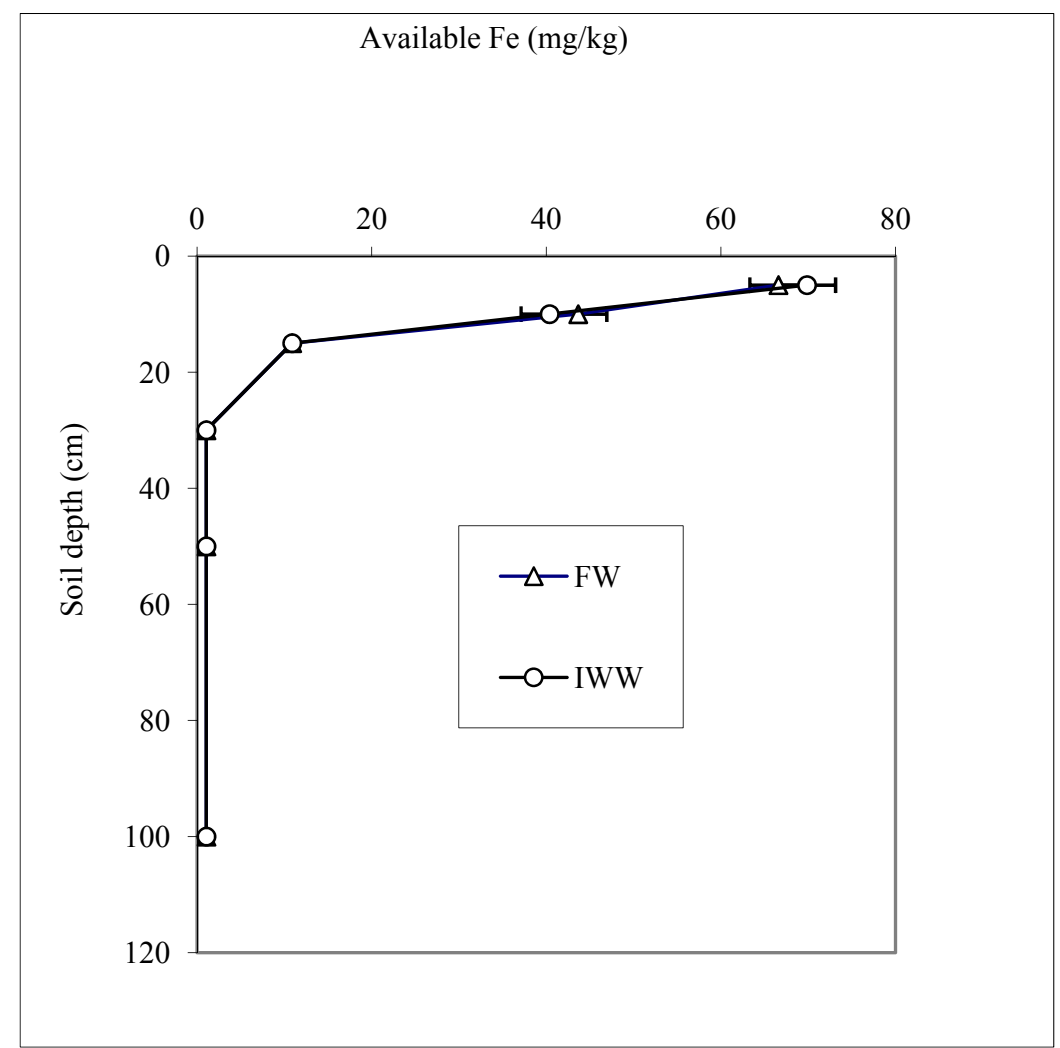

Fig. 13 Distribution of available Fe ( $\mathrm{mg} / \mathrm{kg})$ in soil profiles of industrial effluents contaminated and uncontaminated soils. 
concentration had more or less similar in both the soils. In both the soil profile, the Fe content was decreased with increasing soil depth reflecting Fe enrichment at the surface.

Manganese (Mn) status of different soil depths varied from $20.27 \mathrm{mg} / \mathrm{kg}$ to $50.70 \mathrm{mg} / \mathrm{kg}$ in IWW soils but, in FW soils, it was ranged from $19.08 \mathrm{mg} / \mathrm{kg}$ to $73.97 \mathrm{mg} / \mathrm{kg}$ (Fig. 14). Fresh water irrigated soils showed an increase in Mn content than the IWW soils by $25.65 \mathrm{mg} / \mathrm{kg}, 25.96 \mathrm{mg} / \mathrm{kg}, 17.27 \mathrm{mg} / \mathrm{kg}$ and 8.35 $\mathrm{mg} / \mathrm{kg}$ at $0-5 \mathrm{~cm}, 5-10 \mathrm{~cm}, 10-15 \mathrm{~cm}$ and $15-30 \mathrm{~cm}$ depths, respectively. At 30-50 cm depth, IWW soil gave $4.77 \mathrm{mg} / \mathrm{kg}$ higher, but at $50-100 \mathrm{~cm}$ depth, it gave $8.35 \mathrm{mg} / \mathrm{kg}$ lower $\mathrm{Mn}$ content than the FW soil. In both the soils, the Mn concentration decreased with increasing the soil depth indicating the enrichment of $\mathrm{Mn}$ at the surface. Manganese content was found higher with FW soils in most of the soil layer except at $30-50 \mathrm{~cm}$ depth than the IWW soils, meaning that waste water had no effect on soil profile with respect to $\mathrm{Mn}$.
Copper status of different soils profile varied from $0.46 \mathrm{mg} / \mathrm{kg}$ to $6.91 \mathrm{mg} / \mathrm{kg}$ in IWW soils, but in FW soils, it was ranged between $1.59 \mathrm{mg} / \mathrm{kg}$ to $4.55 \mathrm{mg} / \mathrm{kg}$ (Fig. 15). At $0-10 \mathrm{~cm}$ depth, the $\mathrm{Cu}$ content had higher while from $10-100 \mathrm{~cm}$ depth, it was considerably lower with IWW soils than that of FW soils. In both the soils, the $\mathrm{Cu}$ content decreased with increasing the soil depth, reflecting enrichment of $\mathrm{Cu}$ at the surface. Copper content was higher with FW soil at deeper soil layer than the IWW soil, meaning metals accumulated at the surface. The maximum tolerable concentration of $\mathrm{Cu}$ in soil is $1,000 \mathrm{mg} / \mathrm{kg}$ [25]. Copper concentration of soil in the vicinities in Bangladesh ranged from $28 \mathrm{mg} / \mathrm{kg}$ to $217 \mathrm{mg} / \mathrm{kg}$.

So, all the soil profiles were suitable for crop production with respect to $\mathrm{Cu}$. Trace elements ( $\mathrm{Zn}, \mathrm{Fe}$, $\mathrm{Mn}$ and $\mathrm{Cu}$ ) were found higher in surface soils as compared to sub surface soils. Affinity of metals to organic matter could be responsible for this surface enrichment because of the relatively high organic carbon concentration in the top soil [26].

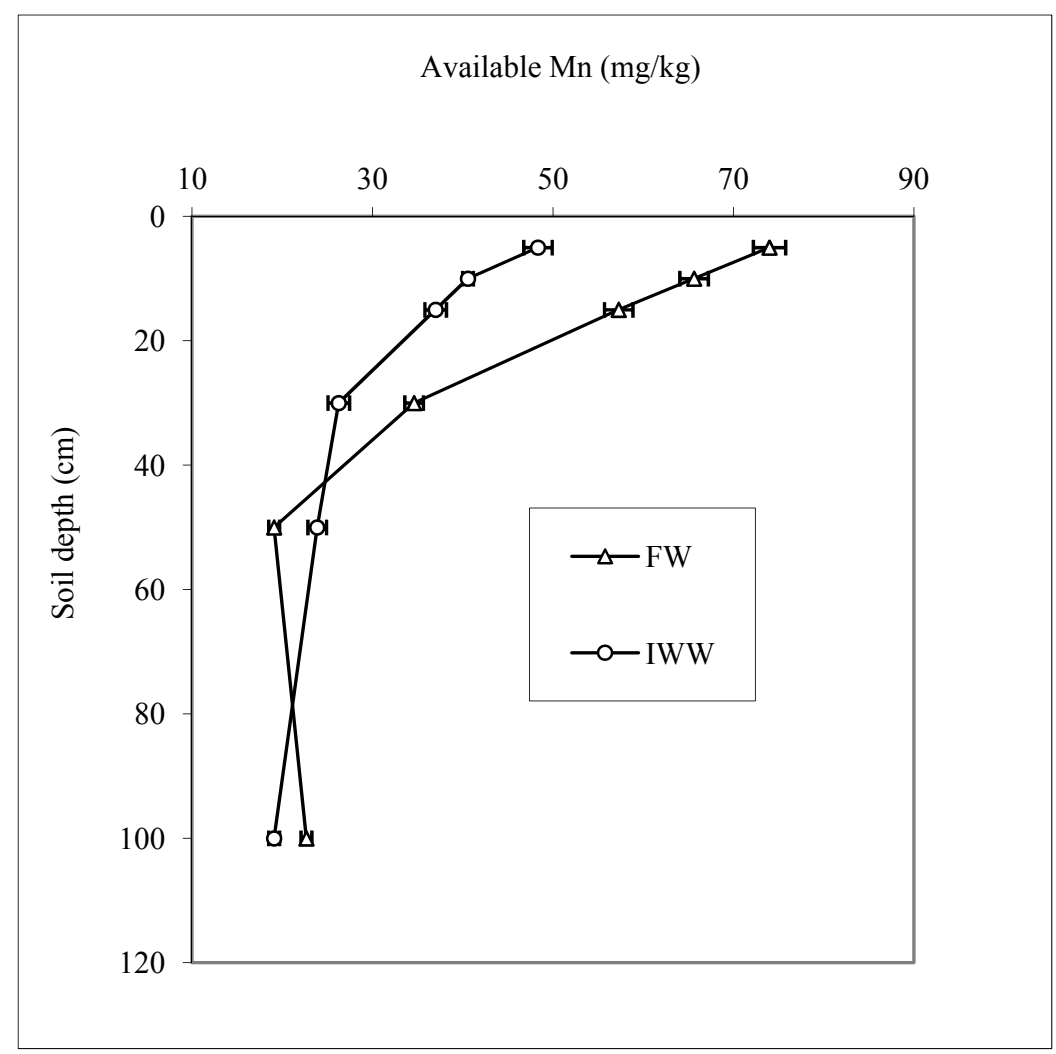

Fig. 14 Distribution of available $\mathrm{Mn}(\mathrm{mg} / \mathrm{kg})$ in soil profiles of industrial effluents contaminated and uncontaminated soils. 


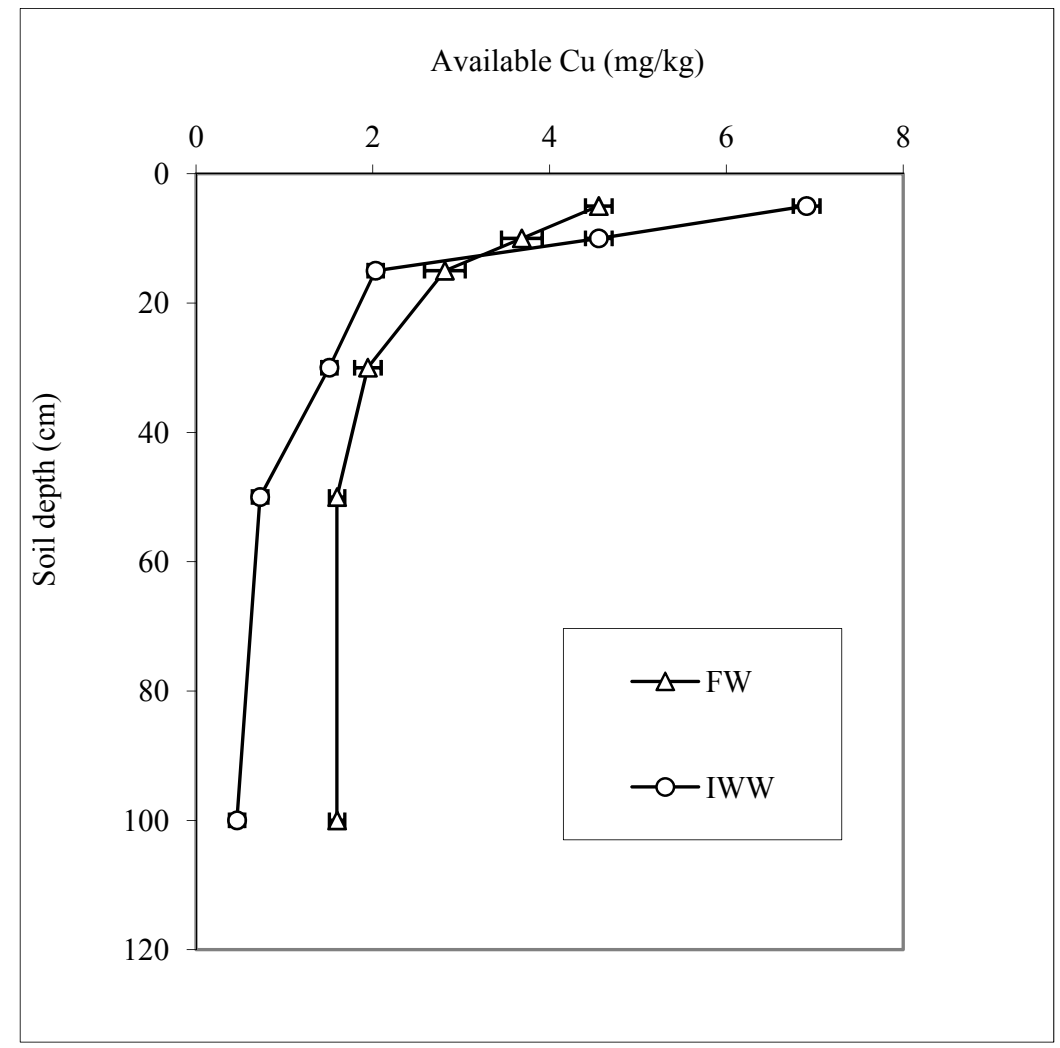

Fig. 15 Distribution of available $\mathrm{Cu}(\mathrm{mg} / \mathrm{kg})$ in soil profiles of industrial effluents contaminated and uncontaminated soils.

\subsection{Heavy Metals ( $\mathrm{Pb}, \mathrm{Cd}, \mathrm{Cr}$ and $\mathrm{Ni})$}

Lead $(\mathrm{Pb})$ content in different soil profile varied from $20 \mathrm{mg} / \mathrm{kg}$ to $27 \mathrm{mg} / \mathrm{kg}$ in FW soils, but in IWW soils, it was varied from $20 \mathrm{mg} / \mathrm{kg}$ to $29 \mathrm{mg} / \mathrm{kg}$ (Fig. 16). A lead content was found to decrease with the increasing soil depth in both the rice soils, reflecting deposition of $\mathrm{Pb}$ at the surface. Similar result was reported by Abdu, N. [1]. Industrial waste water irrigated soils gave 2 units, 1 units and 2 units higher $\mathrm{Pb}$ content than that of control soils at $0-5 \mathrm{~cm}, 5-10$ $\mathrm{cm}$ and 10-15 $\mathrm{cm}$ depths, respectively. But from $15-100 \mathrm{~cm}$ depths, the $\mathrm{Pb}$ concentrations were more or less similar in both the soils. Affinity of surface enrichment of $\mathrm{Pb}$ in waste water treated soils might be due to metals deposition in the surface from the waste water. Ayers, R. S. [25] reported the maximum tolerable concentration of $\mathrm{Pb}$ in soil is $100 \mathrm{mg} / \mathrm{kg}$. From this result, it could be concluded that the profile soils were suitable for the cultivation of rice with respect to $\mathrm{Pb}$.
Cadmium (Cd) concentration of soil profiles varied from $0.18 \mathrm{mg} / \mathrm{kg}$ to $0.23 \mathrm{mg} / \mathrm{kg}$ with FW soils, but in IWW soils, it was ranged between $0.20 \mathrm{mg} / \mathrm{kg}$ to 0.25 $\mathrm{mg} / \mathrm{kg}$ (Fig. 17). In all the soil depths, the Cd content had higher in IWW soils than that of FW soils. Industrial waste water irrigated soils showed an increase in $\mathrm{Cd}$ content than the control soil by 0.02 $\mathrm{mg} / \mathrm{kg}, 0.01 \mathrm{mg} / \mathrm{kg}, 0.01 \mathrm{mg} / \mathrm{kg}, 0.03 \mathrm{mg} / \mathrm{kg}, 0.02$ $\mathrm{mg} / \mathrm{kg}$ and $0.02 \mathrm{mg} / \mathrm{kg}$ at $0-5 \mathrm{~cm}, 5-10 \mathrm{~cm}, 10-15 \mathrm{~cm}$, $15-30 \mathrm{~cm}, 30-50 \mathrm{~cm}$ and $50-100 \mathrm{~cm}$ depths, respectively. Enrichment of Cd in IWW soils might be due to metals deposition from the waste water. From 0-50 cm depth, the $\mathrm{Cd}$ concentrations decreased in both the rice soils, but above $50 \mathrm{~cm}$ depth, the $\mathrm{Cd}$ concentrations were increased in both the soils. It might be due to leaching-related translocation. Pendias, A. K. [27] reported that the maximum tolerable concentration of $\mathrm{Cd}$ in soil is $5 \mathrm{mg} / \mathrm{kg}$. Therefore, all the profile soils contained $\mathrm{Cd}$ beyond tolerable concentration and are suitable for crop production. 


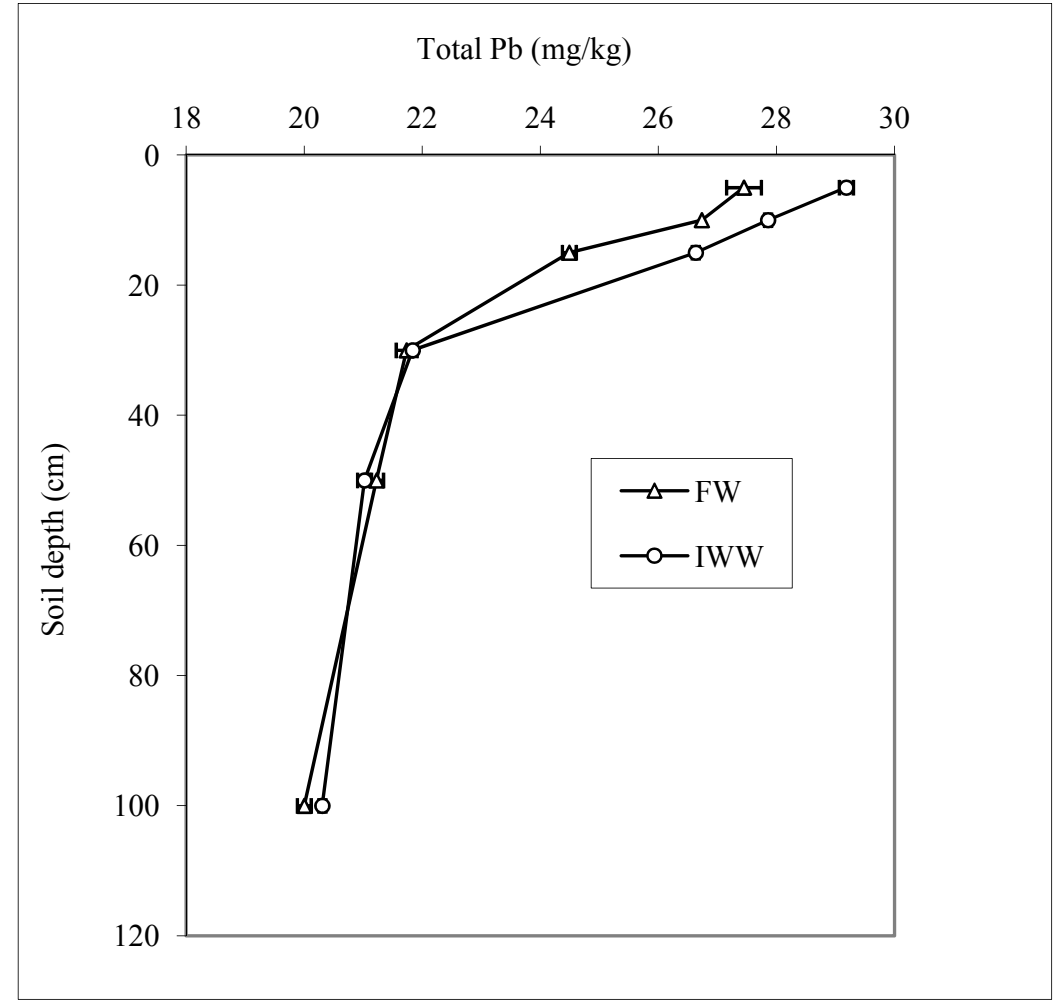

Fig. 16 Distribution of total $\mathrm{Pb}(\mathrm{mg} / \mathrm{kg})$ in soil profiles of industrial effluents contaminated and uncontaminated soils.

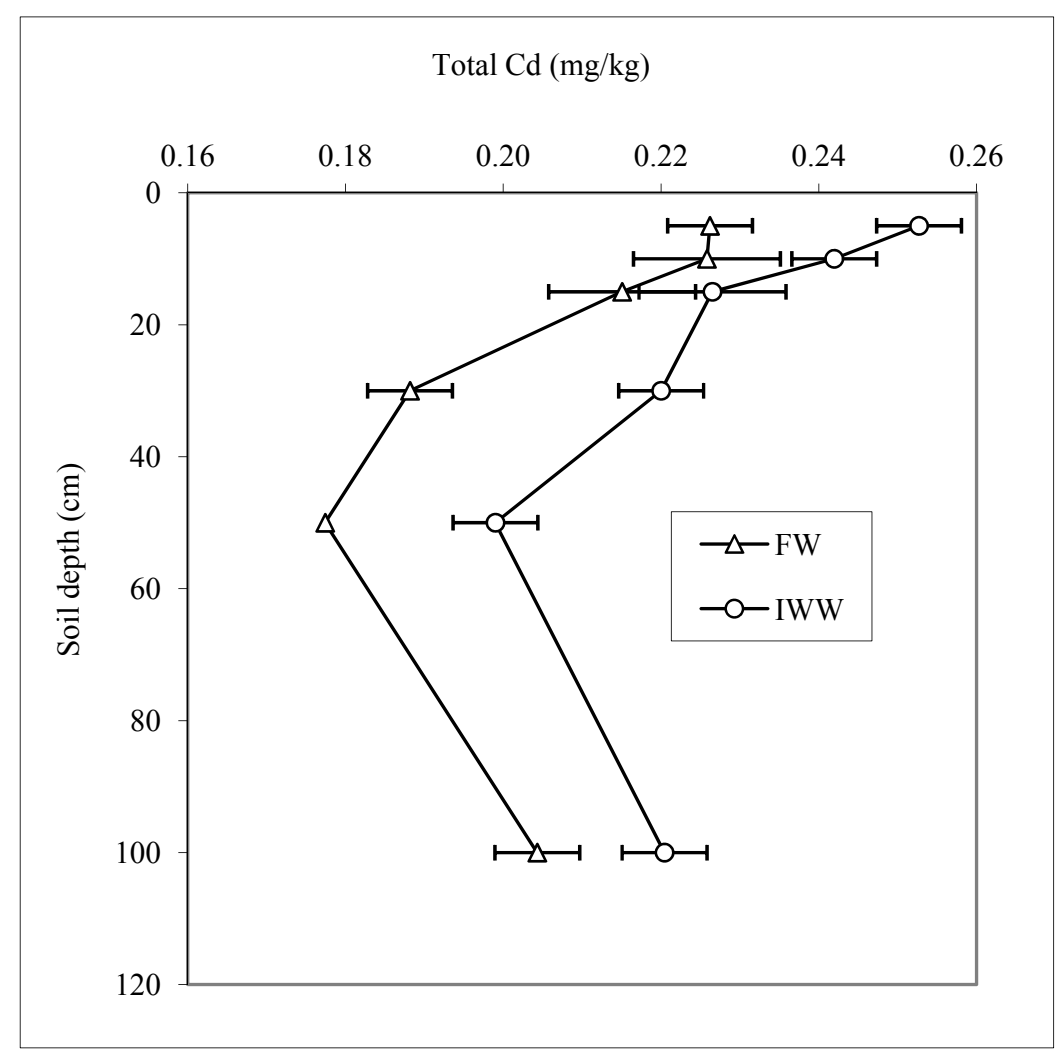

Fig. 17 Distribution of total $\mathrm{Cd}(\mathrm{mg} / \mathrm{kg})$ in soil profiles of industrial effluents contaminated and uncontaminated soils. 
Chromium (Cr) concentration in different soil profiles varied from $44 \mathrm{mg} / \mathrm{kg}$ to $66 \mathrm{mg} / \mathrm{kg}$ in FW soil, but in IWW soils, it ranged between $42 \mathrm{mg} / \mathrm{kg}$ to 74 $\mathrm{mg} / \mathrm{kg}$ (Fig. 18). The IWW soil gave Cr content of 74 $\mathrm{mg} / \mathrm{kg}$ as compared to $66 \mathrm{mg} / \mathrm{kg}$ in $\mathrm{FW}$ soil at $0-5 \mathrm{~cm}$ depth. At 5-10 cm depth, IWW soil had 2 units higher of $\mathrm{Cr}$ content than that of $\mathrm{FW}$ soil. The industrial waste water irrigated soils showed an increase in $\mathrm{Cr}$ content than the $\mathrm{FW}$ soils by $8 \mathrm{mg} / \mathrm{kg}$ and $3 \mathrm{mg} / \mathrm{kg}$ at $10-15 \mathrm{~cm}$ and $15-30 \mathrm{~cm}$ depths, respectively. The FW soils had $7 \mathrm{mg} / \mathrm{kg}$ and $2 \mathrm{mg} / \mathrm{kg}$ higher $\mathrm{Cr}$ content than that of IWW soils at $30-50 \mathrm{~cm}$ and $50-100 \mathrm{~cm}$ depths, respectively. Both in the soils, the $\mathrm{Cr}$ content were found to decrease with the increasing soil depth, reflecting the deposition of $\mathrm{Cr}$ at the surface. Similar result was reported by Abdu, N. et al. [1]. Affinity of surface enrichment of $\mathrm{Cr}$ might be due to metals deposition in the surface from the waste water. Ayers, R. S. and Westcot, D. W. [25] reported that the maximum tolerable concentration of $\mathrm{Cr}$ in soil is 100 $\mathrm{mg} / \mathrm{kg}$. From this result, it could be concluded that the profile soils were suitable for cultivation with respect of $\mathrm{Cr}$.

Nickel (Ni) content in different soil profiles varied from $45 \mathrm{mg} / \mathrm{kg}$ to $66 \mathrm{mg} / \mathrm{kg}$ in FW soils, but in IWW soils, it was ranged between $48 \mathrm{mg} / \mathrm{kg}$ to $72 \mathrm{mg} / \mathrm{kg}$ (Fig. 19). The IWW soil had Ni content of $72 \mathrm{mg} / \mathrm{kg}$ compared to $66 \mathrm{mg} / \mathrm{kg}$ in FW soil at $0-5 \mathrm{~cm}$ depth. At 5-10 cm depth, IWW soil had 2 units higher of Ni content than that of FW soil. At 10-15 cm depth, the Ni content had more or less similar in both the soils. The industrial waste water irrigated soil showed an increase in Ni content than the FW soil by $11 \mathrm{mg} / \mathrm{kg}$, $10 \mathrm{mg} / \mathrm{kg}$ and $3 \mathrm{mg} / \mathrm{kg}$ at $15-30 \mathrm{~cm}, 30-50 \mathrm{~cm}$ and $50-100 \mathrm{~cm}$ depths, respectively. Nickel concentrations were found to decrease with profile depth in both the soils, indicating the deposition of $\mathrm{Ni}$ at the surface.

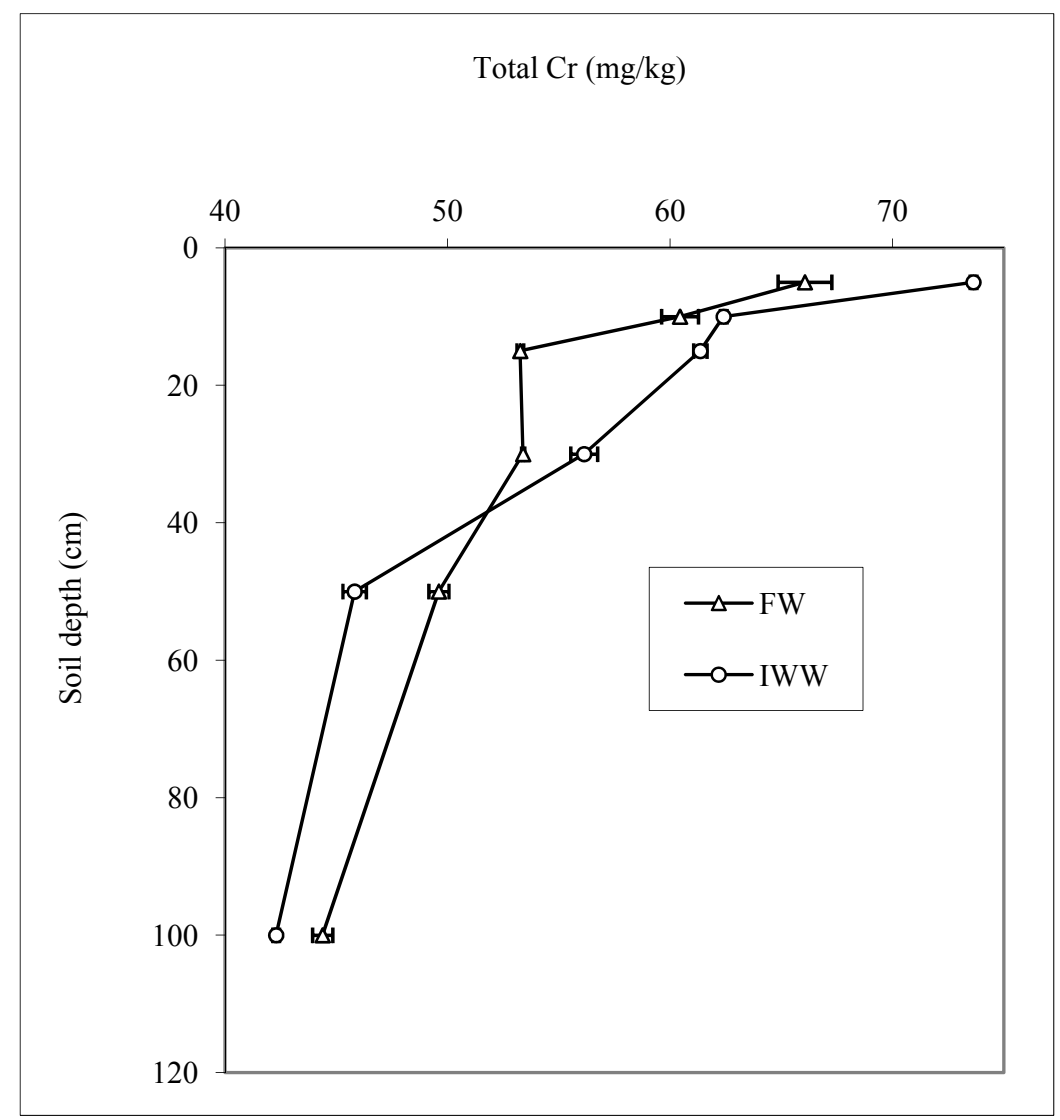

Fig. 18 Distribution of total $\mathrm{Cr}(\mathrm{mg} / \mathrm{kg})$ in soil profiles of industrial effluents contaminated and uncontaminated soils. 


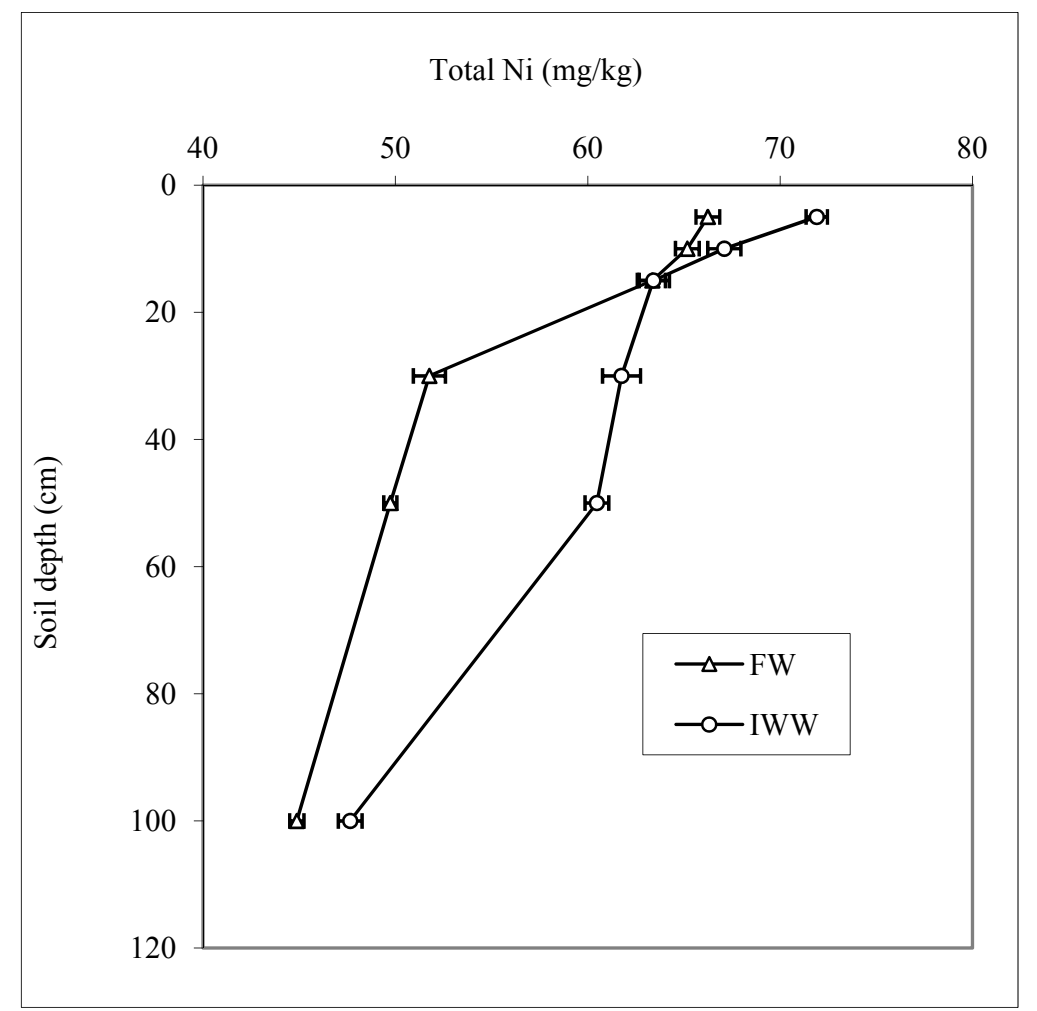

Fig. 19 Distribution of total $\mathrm{Ni}(\mathrm{mg} / \mathrm{kg})$ in soil profiles of industrial effluents contaminated and uncontaminated soils.

Similar result was reported by Abdu, N. et al. [1]. The maximum tolerable concentration of $\mathrm{Ni}$ in soil is $100 \mathrm{mg} / \mathrm{kg}$ [27]. All the profile soils contained Ni beyond tolerable concentrations that are suitable for crop production.

\section{Conclusions}

Results of this experiment showed that the rice soils profile brought a different change in chemical soil properties through long-term industrial waste water irrigation. Industrial waste water irrigated rice field seemed to create some differences in soil $\mathrm{pH}$ at different depth. Relatively more negative charges developed in rice soil through waste water irrigation. Irrigation with industrial waste water increased EC in rice soils profile that developed soil salinity in study area of Gazipur district in Bangladesh. Development of soil salinity in inland associated with the industrial waste water application for rice cultivation is one of the unique findings which would be the great threat for declining soil quality as well as rice production.

\section{References}

[1] Abdu, N., Abdulkadir, A., Agbenin, J. O., and Buerkert, A. 2011. "Vertical Distribution of Heavy Metals in Waste Water Irrigated Vegetable Garden Soils of Three African Cities." Nutr. Cycl. Agroecosyt. 89: 387-397.

[2] Darvishil, H. H., Manshouri, M., and Farahani, H. A. 2010. "The Effect of Irrigation by Domestic Waste Water on Soil Properties." J. Soil Sci. Environ. Mgt. 1 (2): 30-33.

[3] Begum, R. A. 2006. "Assessment of Water and Soil Pollution and Its Effect on Rice and Red Amaranth." Ph.D. thesis, Bangladesh Agricultural University.

[4] Khan, A., Ibrahim, M., Ahmed, N., and Anwar, S. A. 1994. "Studies on Accumulation and Distribution of Heavy Metals in Agricultural Soils Receiving Sewage Effluent Irrigation." In Proc. 4th Natl. Cong. Soil Sci. Islamabad, 607-609.

[5] Qadir, M., 1999. City People Eating Poisoned Vegetables. Pakistan: The Daily Dawn.

[6] Citeau, L., Lamy, I., Oort, F. V., and Elsass, F. 2003. "Colloidal Facilitated Transfer of Metals in Soils under Different Land Use." Colloids Surf. Physicochem. Eng. Asp. 217: 11-19.

[7] Fernandez, C., Labanowski, J., Cambier, P., Jongmans, A. G., and Oort, F. V. 2007. "Fate of Airbone Metal Pollution in Soils as Related to Agriculture Management: 
Zn and Pb Distribution in Soil Profiles.” Eur. J. Soil Sci. 58: 547-559.

[8] Seneviratne, N. M. G. 1997. "Waste Water from Raw Rubber Processing Industry in Srilanka and Related Environmental Aspects." Bull. Rubb. Res. Inst. Sri. 35: 42-48.

[9] Lim, C. A., and Png, T. C. 1983. "Land Application of Digested Palm Oil Mill Effluent by Sprinkler System." In Proceeding of the Seminar on Land Application of Oil Palm and Rubber Factory Effluent, 101-102.

[10] Valdes, E., Obaya, M. C., and Ramos, J. 1996. "Ecology and the Sugar INDUSTRY Revista. J. Biosci. and Agric. Res. 30: 214-229.

[11] Landsberg, H. E. 1981. The Urban Climate, International Geophysics Series. London: Academic Press.

[12] Renger, M. 1993. "Diagnostic Indicators for Characterizing Urban Soils of Szeged, Hungary." Geoderma 148: 267-281.

[13] Businelli, D., Massaccesi, L., and Onofri, A. 2009. "Evaluation of $\mathrm{Pb}$ and $\mathrm{Ni}$ Mobility to Groundwater in Calcareous Urban Soils of Ancona, Italy." Water Air Soil Pollut. 201: 185-193.

[14] Jackson, M. L. 1967. Soil Chemical Analysis. New Delhi: Prentice Hall of India Private Limited.

[15] ] Nelson, D. W., and Sommers, L. E. 1982. Methods of Soil Analysis, Part 2, Total Carbon, Organic Carbon, and Organic Matter. Madison, Wisconsin USA.

[16] Bremner, J. M., and Mulvaney, C. S. 1982. Methods of Soil Analysis Agronomy, Part 2. Madison, Wisconsin: American Society of Agronomy.

[17] Olsen, S. R., and Sommers, L. E. 1982. Methods of Soil
Analysis, Part 2, Phosphorus. Madison: ASA and SSSA.

[18] Murphy, J., and Riley, J. P. 1962. "A Modified Single Solution Method for Determination of Phosphate in Natural Waters." Analytica Chemica. Acta. 27: 31-36.

[19] Thomas, G. W. 1982. Methods of Soil Analysis, Part 2: Exchangeable Cations. Madison, Wisconsin, USA.

[20] Lindsay, W. L., and Norvell, W. A. 1978. "Development of DTPA Soil Test for Zinc, Iron, Copper and Manganese.” Soil Sci. Soci. Amer. J. 42: 421-428.

[21] Poon, Y. C. 1982. "Recycling of Palm Oil Mill Effluent in the Field." In Proceedings of the Rubber Research Institute of Malaysia Kuala Lumpur, 201-2.

[22] Saif, M. S., Haq, M. U., and Memon, K. S. 2005. "Heavy Metals Contamination through Industrial Effluent to Irrigation Water and Soil in Korangi Area of Karachi (Pakistan).” Int. J. Agri. Bio. 7 (4): 646-648.

[23] Sood, R. D., and Kanwar, B. S. 1986. "Distribution of Organic and Total Phosphorus in Some Soil Profile of Different Agroclimatic Zones of Himachal Pradesh." J. Indian Soc. Soil Sci. 34: 404-406.

[24] Haslbach, F. 1984. "The Role of Humus Status of Soils in Binding Toxic Elements and Compounds." The Sci. Total Environ. 81/82: 643-651.

[25] Ayers, R. S., and Westcot, D. W. 1985. "Water Quality for Agriculture." FAO Irrigation and Drainage Paper 29 (1): 196-198.

[26] Agbenin, J. O. 2002. "Lead in a Nigerian Savanna Soil under Long-Term Cultivation.” Sci. Total Environ. 286: $1-14$.

[27] Pendias, A. K. 2001. Trace Elements in Soils and Plants, 3rd Edition. London: CRC Press. 